\title{
Fen Bilgisi Öğretmen Adaylarının Sınıf Yönetimine İlişkin Bilişsel Algılarının Değerlendirilmesi
}

\section{Selçuk ŞAHINGÖZ*}

Öz: Bu çalışmanın amacı fen bilgisi öğretmen adaylarının sınıf yönetimine ilişkin bilişsel algılarını incelemektir. Çalışma kesitsel tarama araştırma yönteminden faydalanılarak yürütülmüştür. Araştırma örneklemini bir devlet üniversitesinde fen bilgisi öğretmenliği bölümünde öğrenim gören 64 öğretmen adayı oluşturmaktadır. Veri toplama aracı olarak iki kısımdan oluşan “Sınıf Yönetimine Yönelik Algı Formu” kullanılmıştır. Formun ilk kısmında metaforik algıları belirlemek amacıyla sınıf yönetimiyle ilgili açık uçlu bir soru yöneltilmiştir. İkinci kısımda ise Kelime İlişkilendirme Testi (KİT) uygulanmıştır. Öğretmen adaylarının ürettikleri metaforik cümleler ve KİT ile yazmış oldukları sınıf yönetimini tanımlayıcı cümleler içerik analizi yapılarak değerlendirilmiştir. KİT aracılığıyla “sınıf yönetimi”, “öğretmen”, “yönetici” ve "lider” anahtar kavramlarıyla ilgili türetilmiş kelimeler frekans tabloları ve kavram ağı oluşturularak yorumlanmıştır. Öğretmen adaylarının sınıf yönetimiyle ilgili en çok “aile” metaforunu kullandıkları tespit edilmiştir. Ön plana çıkan metaforik kategori "kontrol etmek” olmuştur. Sınıf yönetimi anahtar kavramı diğer bir anahtar kavram olan öğretmen kelimesi ile ilişkilendirilmektedir. Öğretmen ve lider anahtar kavramları karşılıklı olarak birbirlerini çağrıştırmaktadırlar. Yönetici anahtar kavramı da en çok müdür kelimesi ile ifade edilmiştir. Öğretmen adayları; kavram ağına göre sınıf yönetimi, öğretmen ve yönetici anahtar kavramlarını okul kelimesinin etrafında toplamaktadır. Sınıf yönetimine yönelik tanımlayıcı cümleler disiplin, iletişim, plan-program ve zaman yönetimi kavramlarını işaret etmektedir.

Anahtar Kelimeler: Bilişsel algı, fen bilgisi öğretmen adayları, metafor, Kelime İlişkilendirme Testi (KİT), sınıf yönetimi

\footnotetext{
*Dr. Öğr. Üyesi, Kastamonu Üniversitesi, Eğitim Fakültesi, Eğitim Bilimleri Bölümü, Email: ssahingoz@kastamonu.edu.tr, Orcid No: 0000-0003-4884-7588.

** Bu araştırma için Kastamonu Üniversitesi Sosyal ve Beşerî Bilimler Araştırma ve Yayın Etik Kurulu Başkanlığı'ndan (30/06/2020 tarih ve 2 sayısı) etik izin alınmıştır.
}

Gönderim:13.10.2020 Kabul:30.12.2020 Yayın:25.01.2021




\section{Evaluation of The Cognitive Perception of Pre-Service Science Teachers Regarding Classroom Management}

Abstract: The purpose of this study is to examine the cognitive perceptions of pre-service science teachers regarding classroom management. The study was conducted using a crosssectional survey research method. The sample of the study consists of 64 pre-service science teachers studying at a state university. Classroom Management Perception Form consisting of two parts was used as data collection tool. In the first part of the form, an open-ended question regarding classroom management was addressed to determine metaphorical perceptions. In the second part, the Word Association Test (WAT) was applied. The metaphor sentences produced by the pre-service teachers and the classroom management descriptive sentences they wrote with the WAT were evaluated by content analysis. The words derived from the key concepts of “classroom management”, “teacher”, “administrator”' and “leader” were interpreted by creating frequency tables and concept network through the WAT. It was determined that the pre-service teacher mostly used "family" metaphor for classroom management. The prominent metaphorical category has been "controlling". The key concept of classroom management is associated with the word teacher which is another key concept. The key concepts of teacher and leader has been derived words that are reciprocally related. The key concept of administrator was expressed mostly with the word manager. According to the concept network, preservice teachers gather the concepts of classroom management, teacher and administrator around the word school. Descriptive sentences for classroom management refer to the concepts of discipline, communication, plan-program and time management.

Keywords: Cognitive perception, pre-service science teachers, metaphor, the Word Association Test (WAT), classroom management

\section{Giriş}

Eğitimde sınıf, her bir üyesinin etkileşim içerisinde bulunduğu sosyal bir alandır (Ming-Tak ve Wai-Shing, 2008). Ayrıca sınıf insanların hayatlarının büyük bir dönemini içerisinde geçirdikleri bir ortam olarak da karşımıza çıkmaktadır. Bu özelliği ile öğrencilerin eğitim-öğretim hayatlarında, öğretmenlerin ise mesleki gelişimlerinde davranışlarını, tutum ve değerlerini şekillendiren önemli bir role sahiptir (Özdemir, 2017). Sınıf denilince akla gelen iki önemli dinamik öğretmen ve öğrencidir. Çağdaş eğitim sisteminde öğrencilerin öğrenmenin merkezine yerleştirilmiş olmasına ve süreç içerisinde daha aktif bir yapıya büründürülmesine rağmen öğretmen halen sınıfta gerçekleşen yaşantıları organize eden ve yönlendiren bir duruşa 
sahiptir. Ayrıca öğretmenin öğretme tarzı ile öğrencinin öğrenme tarzını ortak bir paydada buluşturmak için sınıfta yönetim becerilerine ihtiyaç duyulmaktadır. Bu nedenle başarılı öğretmenlik özellikleri taşımanın en büyük göstergelerinden birisi iyi sınıf yönetimi sergilemektir (Demirel, 2000).

\section{Sınıf Yönetimi}

Alan yazında sınıf yönetimi için çeşitli tanımlar yer almaktadır. Bunlardan ön plana çıkan birkaç tanesine bakacak olursak Evertson ve Weinstein (2006) sınıf yönetimini gerek akademik başarıyı gerekse sosyal ve duygusal öğrenmeleri sağlamak için öğretmenlerin uyguladıkları eylemler ve aldıkları önlemler olarak ifade etmektedir. Diğer yandan Doyle (1986) sınıf yönetimini sınıfta düzeni sağlamak için öğretmenlerin kullandıkları stratejiler ve sergiledikleri faaliyetler olarak belirtmektedir. Weber (2003) sınıf yönetimini öğretmenlerin öğrencilerin öğretim hedeflerine ulaşabilmeleri için öğrenim ortamını oluşturması ve bu ortamı sürekli hale getirmesi olarak tanımlamaktadır. Bu nedenle eğitimde sınıf yönetimi öğrencilerin davranışlarını kontrol etmekten ziyade yapılandırmacı bir öğretim ortamı oluşturmak ve bu yönde rehberlik etmek için kullanılmalıdır (McLeod, Fisher, ve Hoover, 2003, akt. Stronge ve diğerleri, 2004). Brophy (2006) ise sınıf yönetimini fiziksel alan ve kaynakların düzenlenmesi, sınıf içi kuralların oluşturulması ve korunması, rutinler ve prosedürler, öğrencilerin ilgilerini ve dikkatlerini çekmek, disiplin müdahaleleri ve öğrencilerle sosyalleşme eylemleri şeklinde kavramsallaştırarak açıklamaktadır.

\section{Sınıf Yönetiminin Boyutları}

Öğrencilerin sınıfta gerçekleşen yaşantılarının mevcut öğretim programı ve belirlenmiş amaçlar doğrultusunda düzenlenmesi ve yönetilmesinde birinci derecede sorumlu olan kişi öğretmendir (Aydın, 1998). Bu durum öğretmenlerin sınıf yönetiminin içerisinde yer alan unsurları doğru algılaması ve bu unsurlara dayalı uygulamalar gerçekleştirmesini gerekli kılmaktadır. Sınıf yönetimi, bünyesinde farklı boyutları barındıran ve çeşitli faaliyetleri ele alan bir yapıya sahiptir. Genel olarak bu boyutları altı temel başlık altında toplamak mümkündür. Bunlar;

1. Sınıf ortamının fiziksel çevresi (düzeni),

2. Öğretmenin hazırlık zamanı ve dersin sunulma biçimi,

3. Davranış düzenlemeleri (Disiplin),

4. Sınıf içi ilişkilerin düzenlenmesi,

5. Plan-program etkinlikleri ve

6. Zaman yönetimidir (Başar, 2001; Demirtaş, 2007). 
Sınıf yönetiminin gerçekleştiği sınıf ortamının düzenlenmesinde 1sı, 1şık, ses, renk, temizlik, oturma düzeni, ders araç-gereçleri gibi fiziki özelliklerin ayarlanması göz önünde bulundurulmalıdır. Aynı zamanda öğrencilerin gruplandırılması ve gelişim düzeylerine göre bilişsel, duyuşsal ve psikomotor becerilerine bağlı olarak fiziksel çevrenin düzenlenmesi gerekmektedir. Sınıf yönetimini etkileyen bir diğer boyut öğretmenin hazırlık zamanı ve dersi sunma biçimidir. Bu boyutta öğretmenin ses tonu, jest ve mimikleri, göz teması, samimiyeti gibi unsurlar üzerinde durulur.

Sınıf yönetiminin davranış düzenleme veya disiplin boyutunda ise öğretmen ve öğrencilerin ders planına dayalı ortak bir amaç doğrultusunda iş birliği içerisinde birlikte çalışmaları beklenmektedir. Güç ve sorumluluğun öğretmen ve öğrenciler arasında eşit derecede paylaşılması karşılaşılabilecek olası disiplin problemlerinin önüne geçilmesini sağlamaktadır (Zeiger, 2000). Demirtaş (2007) ayrıca davranış düzenlemeleri boyutu içerisinde sınıf ikliminin oluşturulması, istenmeyen davranışların ortaya çıkmadan öngörülerek önlemler alınması veya değiştirilmesi, konulmuş kurallara uyulması gibi konulara da dikkat çekmektedir. Olumlu sınıf iklimi oluşturmak için sınıfta demokratik bir öğrenme ortamı oluşturmak ve istenmeyen davranışları azaltmak amaçlanır (Englander, 1986).

Sınıf içi ilişkilerin düzenlenmesinde ise sınıfta öğrenciler tarafından uyulması istenilen kuralların net bir şekilde ifade edilmesi ve bu kuralların öğrencilere benimsetilmesi istenmektedir. Böylece öğrenciler arasında ve öğrencilerle öğretmen arasında daha iyi bir iletişim kanalı oluşturmak mümkün olacaktır. Öğretmenden bu süreçte etkili iletişim yöntemlerini kullanması ve bu yöntemleri öğrencilere de öğretmesi beklenmektedir.

Sınıf yönetiminin plan-programa dayalı etkinlikler boyutu öğretmenin bir lider rolüne bürünerek Millî Eğitim Bakanlığı’nın belirlemiş olduğu amaçlar doğrultusunda planlamalar yapmasını ve öğretim programına uyarak eğitim-öğretim gerçekleştirmesini hedefler (Ağaoğlu, 2001). Bu boyutta yapılacak etkinliklerin planlanmasının yanı sıra bu etkinliklerin nasıl değerlendirilmesi gerektiği üzerinde de durulmalıdır.

Zaman yönetimi boyutuna geldiğimizde etkili öğrenme için gerekli olan akademik öğrenme süresini arttırmanın ve zaman tuzaklarından sakınmanın yolları aranmaktadır. Ders için gerekli olan ön hazırlıların yapılması, izlencesinin oluşturulması, öğretim etkinliklerinin geçişlerini planlama, ders süresince sözel olsun olmasın sergilenecek tüm davranışların tanımlanması gibi unsurlar dikkate alınır (Murdick ve Hogan, 1996). Kısaca zaman yönetimi tüm ayrıntıları düşünülerek hazırlanan günlük, yıllık ders planları ve bunlara dayalı etkinliklerin uygulanmasının bir yansımasıdır. 


\section{Bilişsel Algı}

Bireyler bilişsel alg1 aracılığıyla bir olguyla ilgili gerçeği veya özelliği duyuşsal ve devinişsel algılarının ötesinde görür veya tanırlar. Bilişsel algının kullanılması kavramsal ve diğer bilişsel ilişkili süreçlerden faydalanılmasını gerekli kılar. $\mathrm{Bu}$ sebeple bireyler tanımladıkları şeyleri bir olgu olarak veya hedeflenen olgunun özelliği olarak ifade ederler. Örüntü oluşumunda ve bir genellemenin yorumlanmasında ön plana çıkan bilişsel algılama, bireylerin bir olgu veya kavramı açıklarken ilgili buldukları yönleri görmemize izin vermektedir. Böylece bilişsel algılarını oluşturan unsurları da dahil ederek bireylerin yapmış oldukları genellemelerin içeriğini ve yapısını anlamamıza olanak sağlamaktadır (Rivera ve Becker, 2008).

\section{Araştırmanın Amacı}

$\mathrm{Bu}$ araştırmada fen bilgisi öğretmen adaylarının sınıf yönetimine ilişkin bilişsel algılarını belirlemek amaçlanmıştır. Bu doğrultuda aşağıda yöneltilmiş olan sorulara cevap aranmıştır:

1) Fen bilgisi öğretmen adayları sınıf yönetimi kavramına yönelik bilişsel algılarını hangi metaforlar ile ifade etmektedirler?

2) Fen bilgisi öğretmen adaylarının sınıf yönetimine yönelik üretmiş oldukları metaforlar ortak özellikleri bakımından hangi kavramsal kategoriler altında toplanmaktadır?

3) KİT'e dayalı olarak fen bilgisi öğretmen adaylarının sınıf yönetimi kavramıyla ilgili anahtar kavramlara yönelik türettikleri kelimeler nelerdir?

4) Fen bilgisi öğretmen adayları KİT aracılığı ile sınıf yönetimine ilişkin bilişsel algılarını nasıl açıklamaktadırlar?

\section{Araştırmanın Önemi}

Sınıf ortamı öğretmenlerin pedagojik alan bilgilerini sergiledikleri en önemli yerdir. Bu nedenle öğretmen adaylarının sınıf yönetimi algılarını başarılı bir şekilde oluşturmaları ve etkili sınıf yönetimi uygulamaları gerçekleştirmeleri gerekmektedir. Alan yazına baktığımızda birçok çalışma özellikle öğretmen adaylarının ve yeterli mesleki deneyime sahip olmayan öğretmenlerin sınıf yönetimi sorunlarıyla boğuştuklarını vurgulamaktadır (Crow, 1991; McCormack, 1997). Ancak az sayıda çalışma öğretmen adaylarının sınıf yönetimini nasıl alg1ladıkları üzerinde durmaktadır (Ekici ve Akdeniz, 2018; Örücü, 2012). Oysaki sınıf yönetiminde başarılı olamamanın ve karşılaşılan sorunları çözememenin altında yatan en önemli nedenlerden birisi sınıf yönetimini yeterli derecede kavrayamamış olmaktır. Sınıf yönetimi kavramı birçok faktöre dayalı olduğu için algılanmasında oldukça karmaşık bir hal 
alabilmektedir. Bu nedenle, eğitimciler tarafından öğretmen adaylarının sınıf yönetimine dair algılarını bilmek onların sınıf yönetimi becerilerini geliştirmekte daha etkili yöntemler uygulamalarına yardımcı olacaktır. Bu araştırmadan elde edilecek bilgiler ışığında öğretmen adaylarının düşünce ve görüşlerinden yola çıkarak sınıf yönetimine bakış açılarının geliştirilmesinde daha etkili bir rehberlik gerçekleştirmenin mümkün olacağı düşünülmektedir.

\section{Yöntem}

\section{Araştırmanın Deseni}

$\mathrm{Bu}$ araştırmada tarama yönteminin türlerinden birisi olan kesitsel taramadan faydalanılmıştır. Kesitsel tarama mevcut tutumları ve durumları ölçerken kullanılmaktadır (Creswell, 2012). Bu tarz araştırma yöntemlerinin farklı avantajları bulunmaktadır (Blackstone, 2012). Bunlardan birisi de öğrencilerin sahip oldukları tutumları, inançları, görüşleri ve benzer birçok özelliğgi incelemede kolaylık sağlamasıdır. Ayrıca eğitim hizmetlerine yönelik ihtiyaçların belirlenmesi ve eğitimin kalitesinin arttırılmasında kullanılabilmesi için ölçümler yapılmasında da yardımcı olmaktadır. Bu doğrultuda gerçekleştirilen araştırmada fen bilgisi öğretmen adaylarının pedagojik gelişimlerinde önemli bir yer tutan sınıf yönetimine yönelik bilişsel algılarının belirlenmesi ve geliştirilmesinde kullanılabilecek veriler kesitsel tarama araştırma yöntemi aracılığıyla saptanmıştır.

\section{Araştırmanın Örneklemi}

Bu çalışmanın örneklemini 2019-2020 eğitim-öğretim yılında Kastamonu Üniversitesi Eğitim Fakültesi Matematik ve Fen Bilimleri Eğitimi Bölümü’nde 4.sınıfta öğrenim görmekte olan 67 fen bilgisi öğretmen adayı oluşturmaktadır. Araştırmaya gönüllü olarak katılmayı kabul eden 64 öğretmen adayı ile çalışma gerçekleştirilmiştir. Bu öğretmen adaylarından 48'i (\%75) kız ve 16'sı (\%25) da erkektir. Çalışma grubunda yer alan öğretmen adaylarının hepsi lisans programları içerisinde bir önceki dönemde sınıf yönetimi dersini almış bulunmaktadırlar. $\mathrm{Bu}$ ders kapsamında çalışmanın literatür kısmında belirtilmiş olan sınıf yönetiminin boyutlarına yönelik bilgileri almış oldukları ders kapsamında öğrenmişlerdir.

\section{Veri Toplama Araçları}

$\mathrm{Bu}$ araştırmada fen bilgisi öğretmen adaylarının sınıf yönetimine ilişkin bilişsel algılarını ölçmek için veri toplama aracı olarak araştırmacı tarafından hazırlanmış olan ve iki kısımdan oluşan "Sınıf Yönetimine Yönelik Bilişsel Algı Formu” kullanılmıştır. Formun ilk kısmında Örücü (2012) tarafindan oluşturulmuş olan metafor formunda metaforik algıları 
belirlemek amacıyla yöneltilen sorulardan esinlenerek sınıf yönetimine ilişkin açık uçlu bir soru olan "Sinıf yönetimi ... benzer, çünkü ... gibidir." sorusu yöneltilmiştir.

Formun ikinci kısımda ise öğretmen adaylarının bilişsel algılarını kavramsal açıdan belirlemek için Kelime İlişkilendirme Testi (KİT) uygulanmıştır. Bu testin temelleri Shavelson (1974) tarafından öğrenciler üzerinde gerçekleştirilen bir bilişsel algı çalışmasıyla atılmıştır. KİT'in temel prensibi bireye sunulan bir kavramın o bireyin zihninde temsil ettiği kavramları tespit ederek bireyin o kavramı algılama şeklinin ifade etmektir. KİT’i uygulayarak bireylerin bir kavramla ilgili bilişsel yapılarını ve bu kavramı algılama biçimlerini başka kelimelerle ilişkilendirerek ölçmek mümkündür (Bahar ve Özatlı, 2003). Böylece bireylerin zihinlerinde oluşturmuş oldukları bilgi ağlarında kurdukları kavramsal bağlantıların anlamlılığı sınanabilir (Özatlı ve Bahar, 2010). Bu çalışmada KİT aracılığıyla öğretmen adaylarına sınıf yönetimi algılarını belirlemek için “'sınıf yönetimi”, “öğretmen”, “yönetici” ve “lider” kavramları olmak üzere 4 anahtar kavram sunulmuştur. Bu anahtar kavramların belirlenmesi sürecinde fen eğitimi ve eğitim yönetimi alanlarında uzman olan üç öğretim üyesinin görüşleri alınmış ve değerlendirilerek nihai karar verilmiştir.

KİT, öğretmen adaylarından kendilerine yöneltilen her bir anahtar kavramla ilgili zihinlerinde çağrışım yapan kelimeleri listelemeleri istenerek uygulanmaktadır. Şekil 1'de de gösterildiği gibi anahtar kavram alt satırlarda tekrar edilmektedir. Böylece üretilen kelimelerin birbiri ile etkileşiminin ve dolayısıyla da istenilenin dışında farklı kelimelerin türetilmesinin önüne geçmek amaçlanmaktadır (Bahar ve Özatlı, 2003).

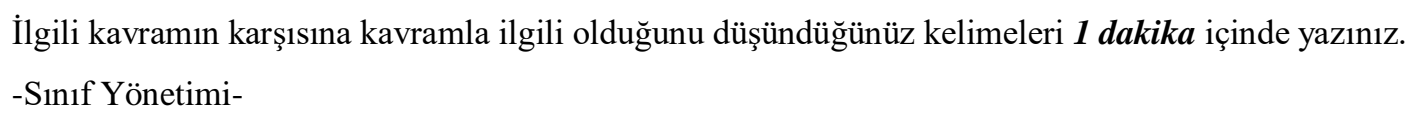

Şekil 1. KİT’ten bir anahtar kavram uygulama örneği

Verilerin toplanması için KİT'in ön uygulama aşamasında benzer diğer araştırmalarda verilen süreler dikkate alınarak bir süre belirlenmiştir. Örneğin, Önal (2017) çalışmasında KİT’i BÖTE öğrencileri üzerinde uygulamıştır ve her bir anahtar kavramla ilgili kavramların türetilmesi için 40 saniye süre vermiştir. Araştırmacı tarafından gerçekleştirilen pilot uygulama ile bu sürenin çalışmada yer alan anahtar kavramlar için yeterli olmadığı gözlenmiştir. Bu doğrultuda, asıl uygulama aşamasında her bir anahtar kavram için katılımcılara 1er dakika süre 
verilmiştir. Ayrıca anahtar kavramla ilgili öğrencilerin bir cümle yazması için de 1 dakika süre verilmiştir.

$\mathrm{Bu}$ çalışmada KİT'in değerlendirilmesinde alışılagelmiş iki tip değerlendirmeden birinin kullanılması yerine her iki tarzı bir araya getirerek bir değerlendirme yapılmıştır. Öncelikle öğretmen adaylarının türettiği her doğru cevaba puan vererek bir test puanı hesaplamak yerine tüm katılımcıların anahtar kavramlarla ilgili türetmiş oldukları kelimelerin tekrarlanma sayısına dayalı olarak frekans tabloları oluşturulmuştur. Ardından öğretmen adaylarından anahtar kavramla ilgili bir cümle yazmaları istenmiştir (bkz. Şekil 1). Burada amaç katılımcıların anahtar kavramla türettikleri kelimeler arasında anlamlı bir ilişki olup olmadığının sağlamasını yapmanın ötesindedir. Asıl amaç frekans tablolarında ön plana çıkan kelimeler ve geliştirilen metaforlar dikkate alınarak sınıf yönetimi kavramıyla ilgili öğretmen adaylarının bilişsel yapılarını derinlemesine inceleyebilmek ve ifade edebilmektir.

Öğretmen adaylarına araştırmacı tarafından veri toplama aracı uygulanmadan önce formda yer alan soruları nasıl cevaplayacaklarına yönelik bilgilendirme yapılmıştır. Bununla birlikte konu dışı bir kavram üzerinden metafor ve KİT için birer örnek verilerek öğretmen adaylarının soruları nasıl cevaplaması gerektiğini daha iyi kavraması sağlanmıştır.

\section{Verilerin Analizi}

Araştırmada verilerin çözümlenme aşamasında içerik analizine başvurulmuştur. İçerik analizi; tanımlayıcı, açıklayıcı ya da tahmin etmeyi amaç edinmiş araştırmalarda tercih edilebilmektedir (Büyüköztürk, Çakmak, Akgün, Karadeniz ve Demirel, 2016). Ayrıca içerik analizi yazılı, sözel ve farklı türde materyaller aracılığıyla elde edilmiş verilerin nesnel bir bakış açısıyla, sistematik bir şekilde çözümlenmesine, kategorize edilerek ve kavramsallaştırarak tanımlanmasına olanak sağlar (Bogdan ve Biklen, 2007; Creswell, 2013; Ekici ve Akdeniz, 2018). Bu çalışmada da fen bilgisi öğretmen adaylarının sınıf yönetimi kavramına yönelik bilişsel algıları üretilmiş belirli metaforlar, türetilmiş kavramlar, tanımlayıcı cümleler ve oluşturulmuş kategoriler etrafinda ele alınarak yorumlanmaya çalışılmaktadır. Böylece çalışmada geçerliliğin ve güvenilirliğin kuvvetlendirilmesi için veri çeşitlemesi (üçlemesi) stratejisinden faydalanılarak çoklu veri toplama ve veri analizi kullanılmıştır (Creswell ve Creswell, 2018; Merriam, 1988).

Öğretmen adaylarının üretmiş oldukları metaforların incelenmesinde içerik analizinin 5 aşamadan oluşan adlandırma, eleme, kategori geliştirme, geçerlik ve güvenirliğin sağlanması, frekansların hesaplanması ve yorumlanması aşamaları takip edilmiştir (Saban, 2009; Çocuk, Yokuş ve Tanrıseven, 2015). Bu doğrultuda öğretmen adayları 1'den başlayarak ÖA1, ..., 
ÖA64 şeklinde kodlanmıştır. Eksik ve geçersiz veriler ayıklandıktan sonra öğretmen adaylarının ürettikleri metaforların gerekçelerine bakılarak kategoriler geliştirilmiştir. Oluşturulan kategorilerin içerisinde yer alan metaforların o kavramsal kategoriyi temsil edip etmediğini belirlemek için eğitim yönetimi alanında uzman üç öğretim üyesinin görüşüne başvurulmuştur. Miles ve Rubennan'ın (1994) geliştirmiş olduğu [(Görüş Birliği/Görüş Birliği + Görüş Ayrılığ1)] x 100 formülü kullanılarak araştırmanın güvenilirliği \%96 olarak hesaplanmıştır. $\mathrm{Bu}$ formülle elde edilen sonucun $\% 90$ ve üzeri olması durumunda güvenilirliğin sağlandığı savunulmaktadır (Saban, 2009). Ardından Microsoft Excel programı aracılığıyla araştırma dahilinde elde edilen metaforlar tekrar etme sıklıklarına ( $f$ ) ve yüzdelerine (\%) göre sıralanarak frekans tabloları oluşturulmuştur. Son olarak üretilen metaforların ortak özelliklerine göre oluşturulan kategori başlıkları ve bu başlıklar altında yer alan metaforlar yine frekanslarına ( $f$ ) göre sıralanarak tablo haline getirilerek yorumlanmıştır.

Öğretmen adaylarının bilişsel algılarını kavramsal açıdan incelemek için KİT aracılığıyla anahtar kavramlara yönelik ürettikleri kelimelerin ayrı ayrı frekans tabloları yapılmıştır. Frekans tablolarına dayalı olarak kelime bulutları oluşturulmuş ve kavram ağı meydana getirilerek yorumlanmıştır. Kavram ağı "Creately” programı aracılığıyla oluşturulmuştur. Kelime bulutlarının hazırlanmasında ise "Wordle” programı kullanılmıştır. Anahtar kavramlarla ilgili türetilen kelimelerin frekans dağılımına bağlı olarak kesme noktaları belirlenmiş ve kavram ağı bu doğrultuda oluşturulmuştur (Örneğin: Ercan ve diğ., 2010). Kesme noktası tekniği kullanılarak 5'erli dört kesme aralığı belirlenmiştir (Bahar, Johnstone, ve Sutcliffe, 1999). KİT’de yer alan her bir anahtar kavram için en fazla üretilen kelimenin tekrar sayısından 5 sayı aşağısı bir kesme noktası olarak hesaplanmış ve dört kesme aralığ tayin edilmiştir. Buna göre kesme aralıkları; 1.Kesme 30 ve yukarısı, 2.Kesme 29-25, 3.Kesme 24-20 ve 4.Kesme 19-15 defa tekrar eden kelime olarak belirlenmiştir. Ayrıca KİT ile öğretmen adaylarından elde edilen tanımlayıcı cümleler, ürettikleri metaforlar ve anahtar kavramlar için türettikleri kelimeler göz önünde tutularak incelenmiş, gerekli kodlamalar yapılmıştır. Elde edilen bulgular bu doğrultuda yorumlanmıştır.

\section{Etik Kurul Kararı}

Kastamonu Üniversitesi Sosyal ve Beşerî Bilimler Araştırma ve Yayın Etik Kurulu'nun, 30/06/2020 tarih ve 2 sayılı kararı gereği çalışma açısından Sosyal ve Beşerî Etik Kuralları ve İlkeleri çerçevesinde herhangi bir sakınca olmadığına karar verilmiştir. 


\section{Bulgular}

Birinci araştırma sorusuna ilişkin "Fen bilgisi öğretmen adayları sınıf yönetimi kavramına yönelik bilişsel algılarını hangi metaforlar ile ifade etmektedirler?” bulgular Tablo 1 'de sunulmuştur.

Tablo 1. Sınıf Yönetimi Kavramına Yönelik Üretilen Metaforların Frekans ve Yüzdelik Dağllımlarl $(N=64)$

\begin{tabular}{|c|c|c|c|c|c|}
\hline $\begin{array}{l}\text { Metafor } \\
\text { Siralaması }\end{array}$ & $\begin{array}{l}\text { Metafor } \\
\text { Sayısı (f) }\end{array}$ & $\begin{array}{c}\text { Metafor } \\
\text { Yüzdesi ( \%) }\end{array}$ & $\begin{array}{c}\text { Metafor } \\
\text { Siralaması }\end{array}$ & $\begin{array}{l}\text { Metafor } \\
\text { Sayısı (f) }\end{array}$ & $\begin{array}{c}\text { Metafor } \\
\text { Yüzdesi ( \%) }\end{array}$ \\
\hline 1. Aile & 10 & 15.70 & 26. İnsan vücudu & 1 & 1,56 \\
\hline 2. Beyin & 3 & 4.70 & 27. Kalp & 1 & 1,56 \\
\hline 3. Baba & 2 & 3.10 & 28. Kaymakam & 1 & 1,56 \\
\hline 4. Evren & 2 & 3.10 & 29. Kendini geliştirmek & 1 & 1,56 \\
\hline 5. Güneş & 2 & 3.10 & 30. Kesişim kümesi & 1 & 1,56 \\
\hline 6. Ülke yönetimi & 2 & 3.10 & 31. Koyun gütmek & 1 & 1,56 \\
\hline 7. Ağaç & 1 & 1.56 & 32. Lego & 1 & 1,56 \\
\hline 8. Anne otoritesi & 1 & 1.56 & 33. Mavi renk & 1 & 1,56 \\
\hline 9. Anne şefkati & 1 & 1.56 & 34. Meclis & 1 & 1,56 \\
\hline 10. Arılar & 1 & 1.56 & 35. Nar & 1 & 1,56 \\
\hline 11. Balık kılçı̆̆ & 1 & 1.56 & 36. Oksijen & 1 & 1,56 \\
\hline 12. Cumhuriyet & 1 & 1.56 & 37. Ordu & 1 & 1,56 \\
\hline 13. Çerçeve & 1 & 1.56 & 38. Orman & 1 & 1,56 \\
\hline 14. Çiftlik & 1 & 1.56 & 39. Öğretmen ve öğrenci & 1 & 1,56 \\
\hline 15. Çocuk büyütmek & 1 & 1.56 & 40. Öğretmenlik hayali & 1 & 1,56 \\
\hline 16. Disiplin & 1 & 1.56 & 41. Parlamento & 1 & 1,56 \\
\hline 17. Ebeveyn & 1 & 1.56 & 42. Sokaktaki insanlar & 1 & 1,56 \\
\hline 18. Elma çekirdeği & 1 & 1.56 & 43. Şirket & 1 & 1,56 \\
\hline 19. Ev & 1 & 1.56 & 44. Toplum & 1 & 1,56 \\
\hline 20. Fabrika işleyişi & 1 & 1.56 & 45. Toplumsal kurallar & 1 & 1,56 \\
\hline 21. Futbol maçı & 1 & 1.56 & 46. Trafik kuralları & 1 & 1,56 \\
\hline 22. Gökyüzü & 1 & 1.56 & 47. Türk Eğitim Sistemi & 1 & 1,56 \\
\hline 23. Grup & 1 & 1.56 & 48. Vücut sistemleri & 1 & 1,56 \\
\hline 24. Güneş sistemi & 1 & 1.56 & 49. Zaman & 1 & 1,56 \\
\hline 25. Hava & 1 & 1.56 & TOPLAM & 64 & 100 \\
\hline
\end{tabular}

Üretilen 49 farklı metafor arasında aile diğer metaforlara oranla net bir şekilde en çok tercih edilen metafor olduğu tespit edilmiştir (bkz. Şekil 2). Bununla birlikte “beyin’”, “baba”, “'evren’’, ‘güneş’” ve “ülke yönetimi’’ öğretmen adayları tarafindan birkaç kez üretilen metaforlar olarak yer almaktadır. 


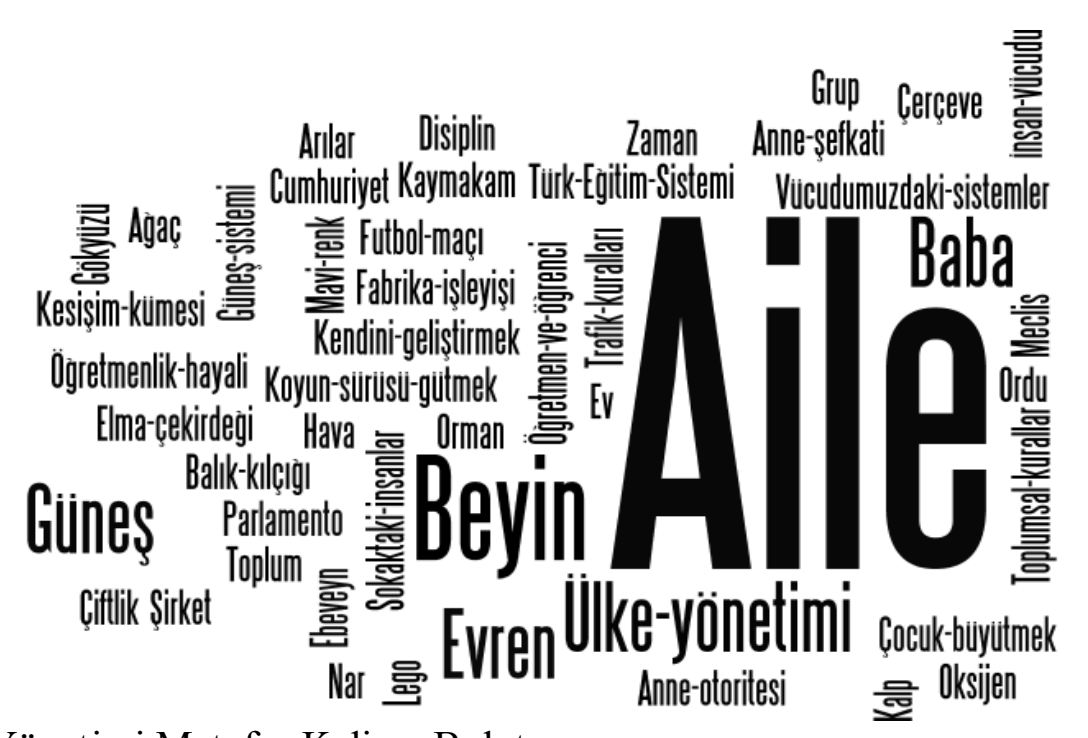

Şekil 2. Sınıf Yönetimi Metafor Kelime Bulutu

“Aile” öğretmen adayları tarafından sınıf yönetimi kavramını ifade ederken en çok kullanılan metafor olmasına (10 kez, \%15,70) rağmen farklı anlamlarda kullanılmıştır. Aile metaforu ile sınıf yönetimini ifade eden beş öğretmen adayının açıklamaları "Birliktelik/Bütünlük/Paylaşım” kategori başlı̆̆ı altında yer almaktadır.

Örneğin;

“Sınıf yönetimi aileye benzer, çünkü hep birliktedir ve her ferdi ayrllmaz bir parçadır.”(ÖA3) “Sınıf yönetimi aileye benzer, çünkü birlik, beraberlik, yardımlaşma içerir.” (ÖA52)

Üç öğretmen adayı bir diğer bakış açısıyla aile metaforunu "Kontrol Etme” kategori başlı̆ğ altında belirtmişlerdir.

Örneğin;

“Sınıf yönetimi aileye benzer; çünkü ögretmen, anne ve babanın otoritesi gibidir.” (ÖA5)

"Sınıf yönetimi aileye benzer, çünkü aile toplumun en küçük parçasıdır ve aileyi yönetmek aslında tüm toplumu yani tüm sinıfi yönetmek gibidir.” (ÖA23)

Diğer kategori başlıklarındaki kadar olmasa da bir öğretmen adayı aile metaforunu “Gereksinimleri Karşılama” kategorisi ve bir öğretmen adayı da "Fiziksel/Kişiliksel Özellikleri Gözetmek” kategori başlıkları içerisinde ifade etmişlerdir.

“Sınıf yönetimi aileye benzer, çünkü kurallar ile öğretmen refah ortam sağlar.” (ÖA47)

"Sınıf yönetimi aileye benzer, çünkü ailede her birey toplumun aynasıdır." (ÖA8)

İkinci araştırma sorusu için "Fen bilgisi öğretmen adaylarının üretmiş oldukları metaforlar hangi kavramsal kategoriler altında toplanmaktadır?” elde edilen bulgular doğrultusunda oluşturulan kategori başlıkları Tablo 2'de sunulmuştur. 
Tablo 2. Sinıf Yönetimi Kavramına İlişkin Metaforlardan Oluşturulan Kategoriler ve Frekanslarl $(N=64)$

\begin{tabular}{|c|c|}
\hline Kategori Başlığı (f) & İlgili Metaforlar (f) \\
\hline Kontrol Etmek (Yönetmek/Otorite) (16) & $\begin{array}{l}\text { Aile*(3), Beyin*(2), Anne otoritesi (1), Arılar (1), } \\
\text { Baba (1), Evren*(1), Futbol maçı (1), Grup (1), } \\
\text { Kaymakam (1), Koyun gütmek (1), Meclis (1), Ordu } \\
\text { (1), Ülke yönetimi*(1) }\end{array}$ \\
\hline Birliktelik/Bütünlük/Paylaşım (12) & $\begin{array}{l}\text { Aile*(5), Ağaç (1), Ev (1), Nar (1), Mavi renk (1), } \\
\text { Lego (1), İnsan vücudu (1), Kesişim kümesi (1) }\end{array}$ \\
\hline Gereksinimleri Karşılamak (8) & $\begin{array}{l}\text { Güneş (2), Aile*(1), Elma çekirdeği (1), Evren*(1), } \\
\text { Hava (1), Kalp (1), Oksijen (1) }\end{array}$ \\
\hline Fiziksel/Kişiliksel Özellikleri Gözetmek (6) & $\begin{array}{l}\text { Aile*(1), Balık kılçığı (1), Cumhuriyet (1), Gökkuşağı } \\
\text { (1), Toplum (1), Ülke yönetimi* (1) }\end{array}$ \\
\hline Düzen/Uyum (5) & $\begin{array}{l}\text { Fabrika işleyişi (1), Güneş Sistemi (1), Toplumsal } \\
\text { kurallar (1), Trafik kuralları (1), Vücut sistemleri (1), }\end{array}$ \\
\hline Geliştirme/Yetiştirme (3) & $\begin{array}{l}\text { Çiftlik (1), Kendini geliştirmek (1), Türk Eğitim } \\
\text { Sistemi (1) }\end{array}$ \\
\hline Sorumluluk/Görev (3) & Beyin*(1), Orman (1), Öğretmen ve öğrenci (1) \\
\hline İletişim/Disiplin (3) & Disiplin (1), Parlamento (1), Şirket (1) \\
\hline İnsancıl Yaklaşım (2) & Öğretmenlik hayali (1), Sokaktaki insanlar (1) \\
\hline Rehberlik (2) & Baba*(1), Ebeveyn (1) \\
\hline Plan/Program (2) & Çocuk büyütme (1), Zaman yönetimi (1) \\
\hline İlgi Göstermek (1) & Anne şefkati (1) \\
\hline Güvenlik/Koruma (1) & Çerçeve (1) \\
\hline
\end{tabular}

* Bu metafor farklı anlamlarda kullanıldığı için birden fazla kategori başlığı altında yer almaktadır.

Öğretmen adaylarının üretmiş oldukları metaforlar ortak özellikleri bakımından kavramsal kategorilere ayrıldığında 13 farklı başlık oluşmaktadır. Bunların arasında ön plana çıkanlar "Kontrol Etmek”, "Birliktelik/Bütünlük/Paylaşım”, "Gereksinimleri Karşılamak”, “Fiziksel/Kişiliksel Özellikleri Gözetmek” ve “Düzen/Uyum” kategorileridir. En çok metaforun toplandığı kategori başlığının "Kontrol Etmek” (16 metafor) olduğu görülmektedir. Farklı metaforlar kullanmış olmalarına rağmen öğretmen adayları sınıf yönetimini ifade ederken yönetmek, otorite kurmak kavramları üzerinde durmaktadırlar.

Örneğin;

“Sınıf yönetimi aileye benzer, çünkü aile içindeki yönetim şekli gibidir.” (ÖA60)

"Sınıf yönetimi beyine benzer, çünkü vücudumuz beyin tarafindan yönetilme ihtiyacı duyar, sinıf da biri tarafindan yönetilme ihtiyacı duyar.” (ÖA6) 
“Sınıf yönetimi orduya benzer, çünkü nasıl kontrol edersen öyle sonuç alırsın.” (ÖA2)

"Sınıf yönetimi futbol maçına benzer, çünkü hakemsiz herkes başına buyruk oynar." (ÖA4)

"Sınıf yönetimi koyun gütmeye benzer, çünkü ögretmen ögrencileri çoban gibi kontrol etmelidir.” (ÖA36)

"Sınıf yönetimi meclise benzer, çünkü ülkeyi yönetmek için ülke adına kararlar alınır.” (ÖA42)

Öğretmen adaylarının üretmiş oldukları metaforların ortak özellikleri bakımından en çok birleştiği ikinci kategori başlığı ise öğrenci ve öğretmen arasında oluşan kuvvetli etkileşim ve iletişime dayalı olan "Birliktelik/Bütünlük/Paylaşım” kategorisidir. Bu başlık altında da birçok farklı metafor yer almasına karşın “'aile”, (5 kez) diğerlerine göre daha çok tercih edilen metafor olmuştur. Bu kategoriye ait metaforlardan birkaç örnek aşağıda yer almaktadır.

"Sınıf yönetimi aileye benzer, çünkü ögrretmen ve ögrenci arasındaki bă̆ ailedeki bireyler arasındaki bă̆ gibidir.” (ÖA9)

"Sınıf yönetimi nara benzer, çünkü içinde bin tane nar tanesi olmasına rağmen kabuğu sayesinde dışarıdan bakılınca bir tane gibi görünür.” (ÖA14)

“Sinıf yönetimi mavi renge benzer, çünkü gökyüzü ve denizin birleşimini ifade eder.” (ÖA17)

"Sınıf yönetimi legoya benzer, çünkü parçalar bir araya geldiğinde anlam kazanır.” (ÖA40)

“Sınıf yönetimi ă̆aca benzer, çünkü ă̆acın bütün dalları sınıfın kendisi gibidir.” (ÖA64)

Üretilen metaforların (8 metafor) özellikleri bakımından en çok ortak paydada toplandığ1 bir diğer kategori başlığı öğrencilerin ihtiyaçlarına odaklanan "Gereksinimleri Karşılamak" olarak görülmektedir. Bu kategoriye ait birkaç metafor örneği aşağıda yer almaktadır.

"Sınıf yönetimi havaya benzer, çünkü yaşamak için havaya ihtiyacımız var, sınıfta düzeni sağlamak için de sınıf yönetimine ihtiyacımız var.” (ÖA16)

"Sinıf yönetimi elma çekirdeğine benzer, çünkü elmanın çekirdeği olmadan elma meyvesi oluşmaz.” (ÖA38)

"Sinıf yönetimi oksijene benzer, çünkü oksijen olmazsa insanlar hatta çoğu canlı olmaz, sınıf yönetimi olmazsa da sinıf denen kavram olmaz.” (ÖA57)

Üçüncü araştırma sorusu için “KİT’e dayalı olarak fen bilgisi öğretmen adaylarının sınıf yönetimi kavramıyla ilgili anahtar kavramlara yönelik türettikleri kelimeler nelerdir?” elde edilen bulgular Tablo 3,4,5,6 ve 7'de sunulmuştur.

Tablo 3’te sınıf yönetimi kavramı ile ilişkilendirilmiş dört anahtar kavram için türetilmiş olan kelime sayıları sunulmaktadır. Tablo 3'te ayrıca anahtar kavramlar için türetilmiş olan toplam kelime sayısı ile birlikte türetilen farklı kelime sayısı ve bunun toplam 
üretilen kelime sayısındaki yüzdesine de yer verilmiştir. Fen bilgisi öğretmen adaylarının en çok “öğretmen”’ anahtar kavramına yönelik kelime türettikleri (693 kelime) görülmüştür. Bunu sırasıyla “yönetici” (609 kelime), “sınıf yönetimi”’ (570 kelime) ve “lider”’ (564 kelime) anahtar kavramları için türetilen kelime sayıları izlemektedir.

Tablo 3. Anahtar Kavramlar ve Türetilen Kelime Sayıları

\begin{tabular}{lcc}
\hline Anahtar Kavram & Toplam Kelime Sayısı & Farklı Kelime Sayısı \\
\hline Sınıf Yönetimi & 570 & 184 \\
Öğretmen & 693 & 251 \\
Yönetici & 609 & 246 \\
Lider & 564 & 243 \\
\hline
\end{tabular}

Tablo 4’te ilk anahtar kavram olan sınıf yönetimi için öğretmen adaylarının türetmiş oldukları kelimelerden öne çıkanlar tekrar sayısına ve türeten kişi yüzdesine göre sunulmaktadır. Sınıfin en önemli dinamikleri olan ögrretmen (diğer bir anahtar kavram) (46 kez, \%71,88) ve öğrenci (44 kez, \% \%8,75) öğretmen adaylarının çoğunluğu tarafından türetilen kelimeler olarak göze çarpmaktadır.

Tablo 4. Sınıf Yönetimi Anahtar Kavramına Yönelik Türetilmiş Öne Çıkan Kelimeler ve Türeten Kişi Yüzdeleri

\begin{tabular}{lcc}
\hline Kelime & Frekans (f) & Türeten Kişi Yüzdesi ( \%) (N=64) \\
\hline Öğretmen & 46 & 71,88 \\
Öğrenci & 44 & 68,75 \\
Sinıf Ortamı & 26 & 40,63 \\
Disiplin & 23 & 35,94 \\
Liderlik & 21 & 32,81 \\
Zaman Yönetimi & 19 & 29,69 \\
Sinıf Kuralları & 18 & 28,13 \\
Okul & 15 & 23,44 \\
Düzen & 14 & 21,88
\end{tabular}

Türetilen kelimeler içerisinde “'sınıf ortamı” (26 kez, \%40,63), “disiplin” (23 kez, \%35,94), “liderlik”, (diğer bir anahtar kavram) (21 kez, \%32,81), “zaman yönetimi”' (19 kez, \%29,69), “sinıf kuralları” (18 kez, \%28,13), okul (15 kez, \%23,44) ve “düzen”' (14 kez, $\% 21,88$ ) ön plana çıkan diğer kelimelerdir (bkz. Şekil 3). 


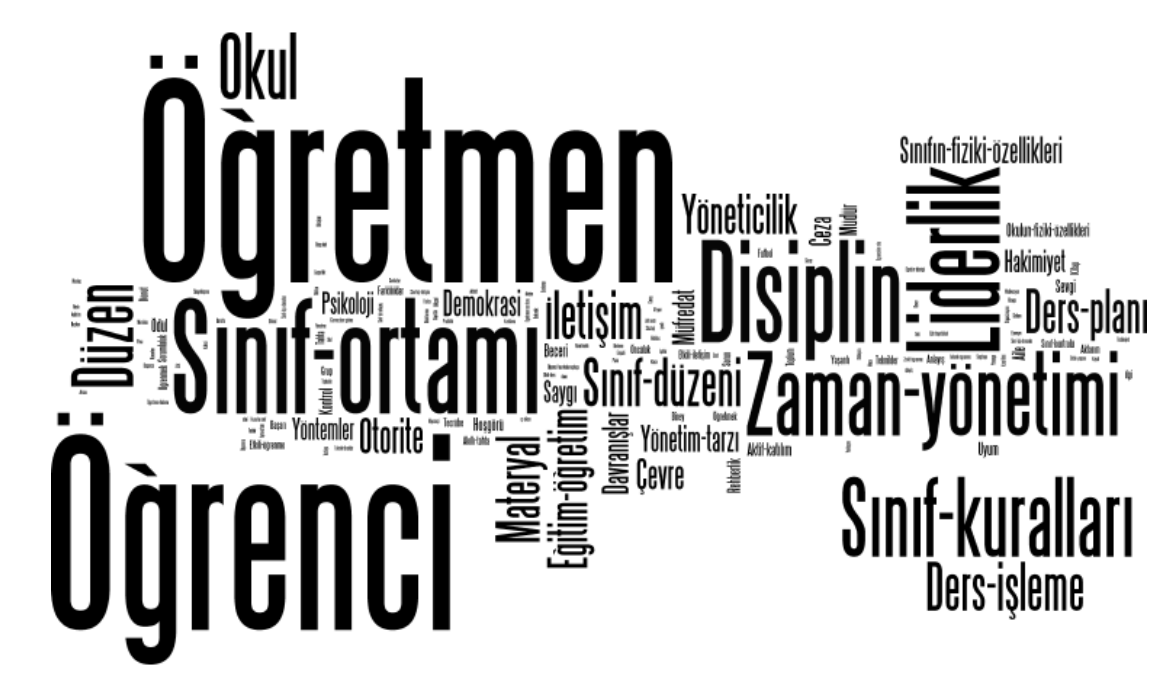

Şekil 3. Sınıf Yönetimi Anahtar Kavramı Kelime Bulutu

Tablo 5’te ikinci anahtar kavram olan “öğretmen” için öğretmen adaylarının ön plana çıkartmış oldukları kelimler bir önceki tabloda olduğu gibi frekans ve kelimeyi türeten kişi yüzdesine göre sıralanarak sunulmaktadır. $\mathrm{Bu}$ anahtar kavram için en çok tekrar edilen kelimenin bir diğer anahtar kavram olan "lider”' (29 kez, \%45,31) kelimesi olduğu görülmektedir. Öğretmen adaylarının neredeyse yarısı öğretmen kavramını lider kelimesi ile ilişkilendirmektedirler.

Tablo 5. Öğretmen Anahtar Kavramına Yönelik Türetilmiş Öne Çıkan Kelimeler ve Türeten Kişi Yüzdeleri

\begin{tabular}{lcc}
\hline Kelime & Frekans (f) & Türeten Kişi Yüzdesi ( \%) (N=64) \\
\hline Lider & 29 & 45,31 \\
Bilgili & 24 & 37,50 \\
Öğrenci & 23 & 35,94 \\
Okul & 22 & 34,38 \\
Sınıf & 20 & 31,25 \\
Rehber & 19 & 29,69 \\
Öğreten & 18 & 28,13 \\
Sevgi & 17 & 26,56 \\
Anne & 15 & 23,44 \\
Yönetici & 15 & 23,44
\end{tabular}

Türetilen kelimeler arasında "bilgili”' (24 kez, \%37,50), “öğrenci” (23 kez, \%35,94), “okul”' (22 kez, \%34,38), “sin1f”' (20 kez, \%31,25), “rehber”' (19 kez, \%29,69), “öğreten’” (18 kez, \%28,13), “sevgi” (17 kez, \%26,56), “anne” (15 kez \%23,44) ve diğer bir anahtar kavram olan “yönetici”' $(15 \mathrm{kez}, \sim \% 23,44)$ ise öne çıkan diğer kelimeler olarak yer almaktadır (bkz. Şekil 4). 


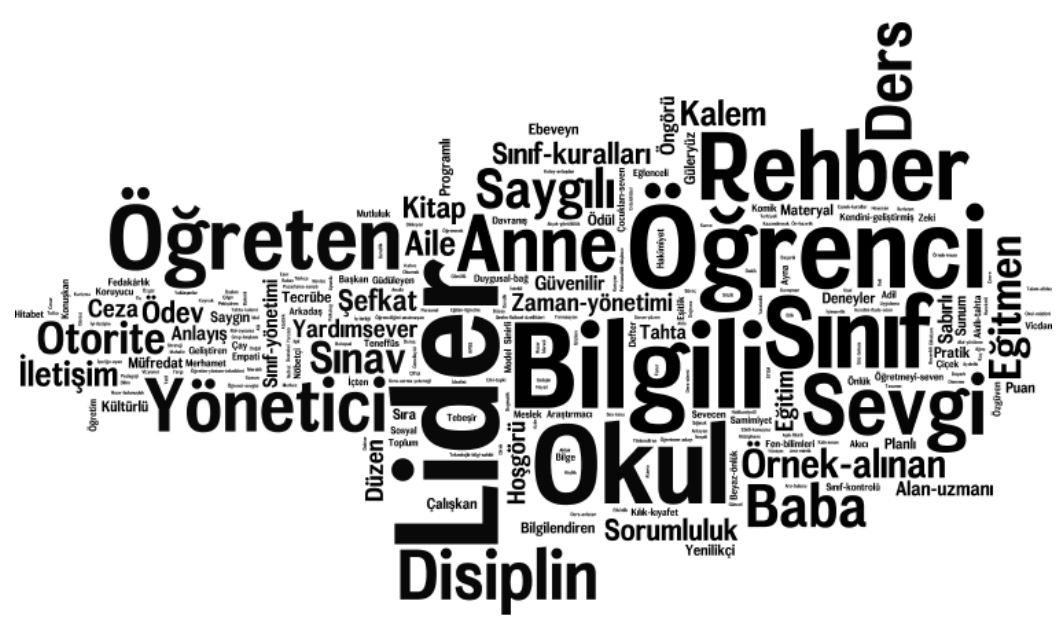

Şekil 4. Öğretmen Anahtar Kavramı Kelime Bulutu

Üçüncü anahtar kavram olan “yönetici” için türetilmiş olan kelimeler türeten kişi yüzdeleri ile birlikte frekanslarına göre Tablo 6'da sunulmaktadır. Öğretmen adaylarının yarısından fazlası için bu anahtar kavramı görünce zihinlerinde müdür (33 kez, \%51,56) kelimesinin çağrışım yaptığı görülmektedir.

Tablo 6. Yönetici Anahtar Kavramına Yönelik Türetilmiş Öne Çıkan Kelimeler ve Türeten Kişi Yüzdeleri

\begin{tabular}{lll}
\hline Kelime & Frekans & Türeten Kişi Yüzdesi ( \%) (N=64)
\end{tabular}

(f)

\begin{tabular}{lll}
\hline Müdür & 33 & 51,56 \\
Öğretmen & 22 & 34,38 \\
Disiplin & 20 & 31,25 \\
Lider & 19 & 29,69 \\
Okul & 17 & 26,56 \\
Kurallar & 17 & 26,56 \\
Otorite & 14 & 21,88 \\
Sorumluluk & 14 & 21,88 \\
Müdür Yardımcisı & 13 & 20,31 \\
Yöneten & 11 & 17,19 \\
\hline
\end{tabular}

Anahtar kavramlardan birisi olan “öğretmen”' kelimesinin yönetici anahtar kavramı yönelik öğretmen adaylarının yaklaşık üçte biri $(22 \mathrm{kez,} \sim \% 34,38)$ tarafından en çok türetilen ikinci kelime olduğu tespit edilmiştir. “Disiplin” (20 kez, \%31,25), “lider” (19 kez, \%29,69), “okul”' (17 kez, \%26,56) ve “kurallar”' (17 kez, \%26,56) türetilmiş olan diğer dikkat çekici kelimler olarak yer almaktadırlar (bkz. Şekil 5). 


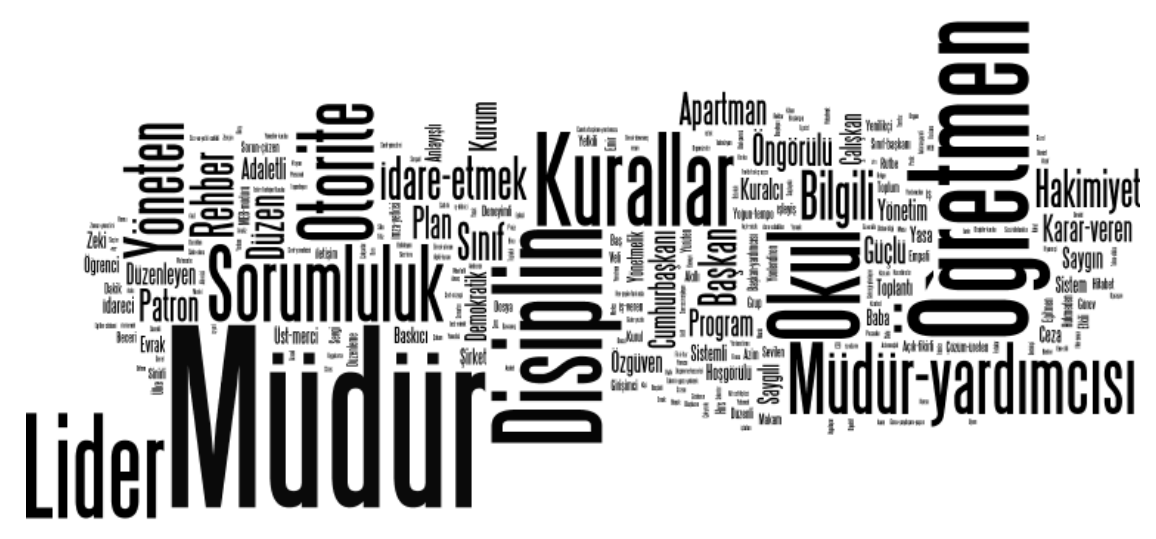

Şekil 5. Yönetici Anahtar Kavramı Kelime Bulutu

Tablo 7’de son anahtar kavram olan “lider”' için türetilmiş kelimelere baktığımızda “yönetici”'de olduğu gibi anahtar kavramlardan birisi olan “öğretmen”' (19 kez, \%29,69) kelimesinin “Atatürk” (19 kez, \% 29,69) kelimesi ile birlikte öğretmen adayları tarafından en çok türetilen kelime olduğu görülmektedir.

Tablo 7. Lider Anahtar Kavramına Yönelik Türetilmiş Öne Çıkan Kelimeler ve Türeten Kişi Yüzdeleri

\begin{tabular}{lcc}
\hline Kelime & Frekans (f) & Türeten Kişi Yüzdesi ( \%) (N=64) \\
\hline Atatürk & 19 & 29,69 \\
Öğretmen & 19 & 29,69 \\
Öngörülü & 17 & 26,56 \\
Sorumluluk Sahibi & 16 & 25,00 \\
Önder & 14 & 21,88 \\
Yönetici & 13 & 20,31 \\
Bilgili & 12 & 18,75 \\
Rehber & 11 & 17,19 \\
Başkan & 10 & 15,63 \\
Otoriter & 10 & 15,63
\end{tabular}

Diğer anahtar kavramlar için türetilen kelimelerin dağılımına baktığımızda birkaç kelimenin bariz şekilde daha fazla türetildiği fark edilmektedir. Ancak “'lider”’ anahtar kavramı için türetilen kelimelerden birçoğunun birbirine yakın frekans ve türeten kişi yüzdeleri ile ön plana çıktığ1 görülmektedir. Özellikle “Atatürk” (19 kez, \%29,69), “öğretmen” (diğer bir anahtar kavram) (19 kez, \%29,69), “öngörülü’’ (17 kez, \%26,56), “sorumluluk sahibi” (16 kez, $\sim 25,00$ ) dikkat çeken türetilmiş kelimelerdir (bkz. Şekil 6). 


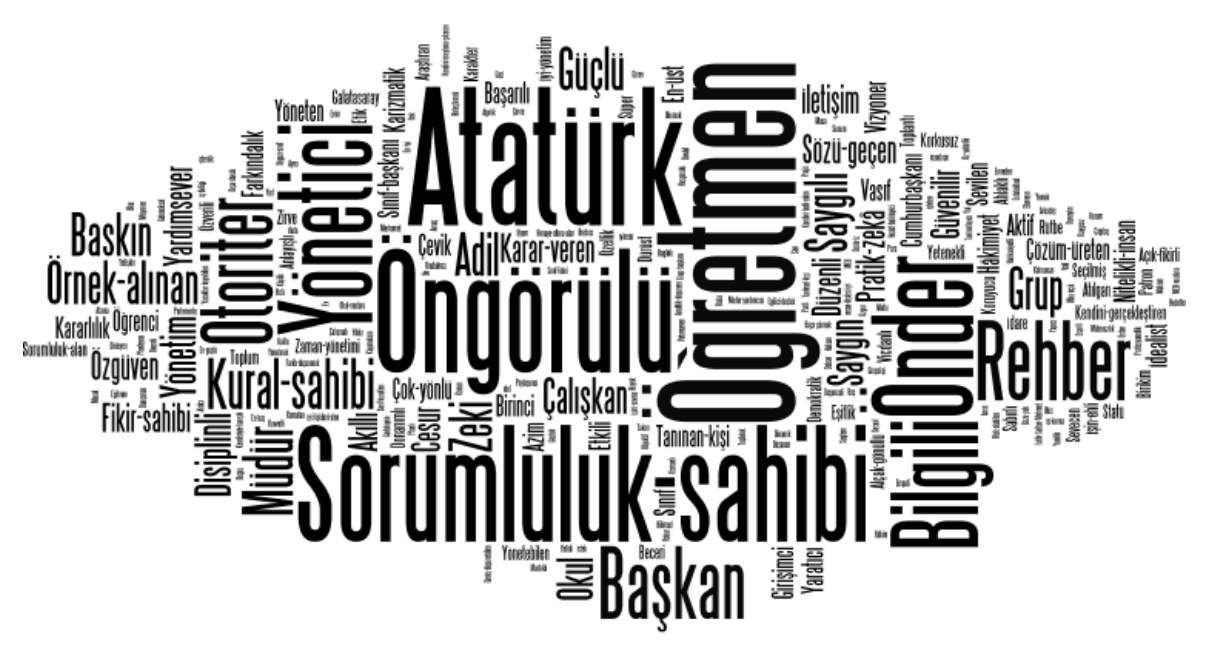

Şekil 6. Lider Anahtar Kavramı Kelime Bulutu

Öğretmen adaylarının anahtar kavramlarla ilişkilendirdikleri kelimeler frekans tablolarında yer alan değerleri doğrultusunda kesme noktalarına ayırılarak bir kavram ağ oluşturulmuştur. Şekil 7'de anahtar kavramlar ve bunlara yönelik türetilmiş kelimeler arasındaki ilişkiler gösterilmiştir. Kavram ağında anahtar kavramlar yeşil renkle yer almaktadır. Beşerli dört kesme aralığına göre (Bknz. 2.4. Verilerin analizi) her bir kesme farklı renklerle 1.Kesme (yeşil), 2.Kesme (mavi), 3.Kesme (turuncu) ve 4.Kesme (mor) ifade edilmektedir. Türetilmiş kelimelerden sadece bir anahtar kavram kapsamında türetilmiş olanları kahverengi, iki anahtar kavram kapsamında türetilmiş ise lacivert ve üç farklı anahtar kavram kapsamında türetilmiş bir kelime ise kırmızı renkle vurgulanarak sunulmaktadır.

Bunun dışında “öğretmen”, ve “yönetici”, anahtar kavramları arasında karşılıkla bir ilişki olduğu, “sınıf yönetimi’’nden “lider’’e ve “yönetici”'den “lider”' anahtar kavramına yönelik tek yönlü ilişki olduğu da görülmektedir.

Anahtar kavramların türetilen kelimelerle ilişkisine bakıldığında “sınıf ortamı” ve “öğrenci”’ kelimeleri hem “sınıf yönetimi”, hem de “öğretmen” anahtar kavramlarına yönelik türetilen kelimeler içerisinde yer almaktadır. Benzer şekilde “'kurallar”’ ve “disiplin”, kelimeleri de hem “'sınıf yönetimi”' hem de 'yönetici”' anahtar kavramları için türetilmiş olan ortak kelimeler olarak gözlenmektedir. “'Okul”’ kelimesinin ise “lider”' hariç diğer tüm anahtar kavramlar için ortak olarak türetilen kelime olduğu dikkat çekmektedir. 


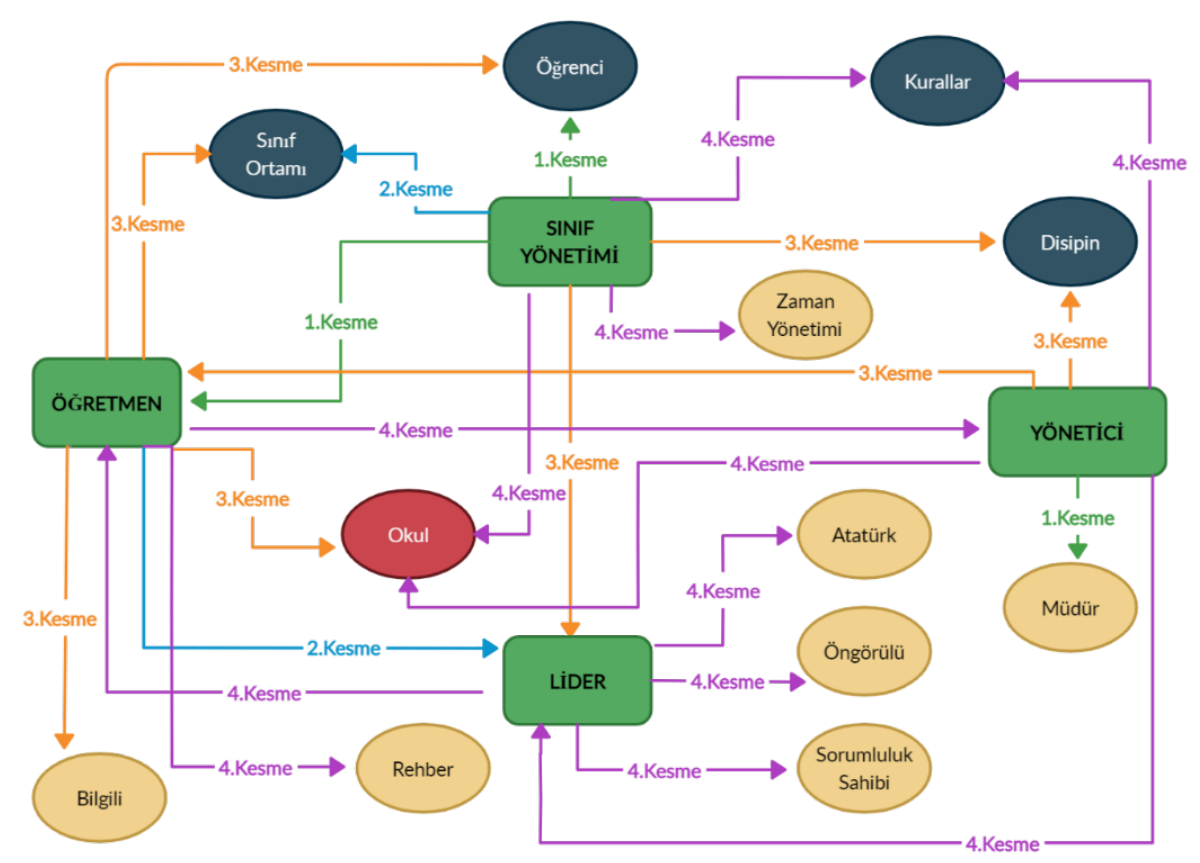

Şekil 7. Sınıf Yönetimi İçin Oluşturulan Anahtar Kavramlara Yönelik Kavram Ağ1

Dördüncü araştırma sorusu için "Fen bilgisi öğretmen adayları KİT aracıllı̆̆ ile sınıf yönetimine ilişkin bilişsel algılarını nasıl açıklamaktadırlar?” elde edilen bulgular öğretmen adaylarına ait açıklamalardan alıntılar yapılarak sunulmuştur.

Sınıf yönetimine yönelik sunulmuş olan tanımlayıcı cümleler incelendiğinde öğretmen adaylarının özellikle “disiplin”, “iletişim”’, “plan-program” ve “zaman yönetimi’” kavramlarını ön plana çıkardıkları gözlenmiştir. Sınıf yönetimini ifade ederken en çok “'disiplin’’ kavramı üzerinde durdukları ve disiplini öğrenciyi kontrol etmek, yönetmek ya da öğrenci üzerinde hâkimiyet kurmak şeklinde açıklamaktadırlar. Öğretmen adaylarının yazmış oldukları cümlelerden birkaç örnek şu şekildedir:

"SInıf yönetimi iç ve dış etkenleri bilip sınıfta oluşabilecek disiplini bozacak davranışların engellenmesidir.’’ (ÖA25)

“Sınıf yönetimi sınıfta öğrencilerin hal, hareket ve duygularını kontrol etme işidir.’ (ÖA2)

“'Sınıf yönetimi belli bir amaç için toplanmış bir grubu idare etmektir.” (ÖA46)

"Sınıf yönetimi bir sınıfın hâkimiyetinin sağlanarak öğrencilere en iyi şekilde ĕgitim verilmesidir.", (ÖA62)

Sınıf yönetimini tanımlayıcı cümlelere bakıldığında “iletişim”’ kavramının disiplinden sonra en çok dikkate alınan kavram olduğu görülmektedir. İletişimin daha etkili ve karş1lıklı diyalog şeklinde kurulması üzerinde durulmaktadır. Öğretmen adaylarının yazmış oldukları cümlelerden birkaç örnek şu şekildedir: 
“Sinıf yönetimi iletişimi temel alarak ögrenci-öğretmen arasında kuvvetli temellerin atılması ve gerekli öğrenme ortamının bu sayede oluşturulmasıdır.’, (ÖA33)

"Sınıf yönetimi öğretmenlerin etkili iletişimi ile öğrencileri etkisi altına alması ve konuları kalıcı şekilde öğretmeye çalışırken karşılıklı diyalog kurulmasıdır.’’ (ÖA49)

"SInıf yönetimi öğretmenin lider kişilikli yapısı ile etkili iletişim kurarak ĕğitim ortamını düzenlemesidir.’, (ÖA13)

Ayrıca öğretmen adaylarının sınıf yönetimini açıklarken " planlı ve programlı olma”, gereksinimi üzerinde de durdukları anlaşılmaktadır. Plan ve programı etkili ders işleme ve sınıfta istenen düzenin oluşturulabilmesi ile ilişkilendirerek sınıf yönetimini tanımladıkları fark edilmektedir. Öğretmen adaylarının yazmış oldukları cümlelerden birkaç örnek şu şekildedir: “Sınıf yönetimi ögretmenin derse gelmeden önce belirli bir günlük plana göre ilerleyerek ve derse geldiğinde de süreyi iyi planlayarak sınıfa hâkim olmasıdır’ (ÖA56)

"Slnıf yönetimi belli bir alanda belli bir zamanda yapılan eğitimin planlanıp programlanmasıdır. Bazı durumlara göre de bu planın esnek olmasıdır.” (ÖA26)

“SInıf yönetimi bir ögretmenin bir dersi verimli şekilde işleyebilmesi için uyguladı̆̆ tasarıları kapsayan ve öğretmende olmast gereken bir beceridir." (ÖA14)

Öğretmen adaylarının ‘zaman yönetimi’’ni de yine sınıf yönetimini betimlerken önemli bir kavram olarak kullandıkları tespit edilmiştir. Öğretmen adaylarının yazmış oldukları cümlelerden birkaç örnek şu şekildedir:

"Sınıf yönetimi öğretmenin zamanı düzgün kullanarak etkili bir öğrenme ortamı hazırlamasıdır.,' (ÖA36)

“Sınıf yönetimi sınıfta bir otorite kurmanın aksine ögrencileri ve zamanı iyi bir liderlik özelliği göstererek yönetmektir.’' (ÖA13)

\section{Tartışma ve Sonuç}

Başarılı bir öğretmen olmanın yolu etkili sınıf yönetiminden geçmektedir. Bunun için sınıf yönetiminin ne demek olduğunu iyi anlamak gerekir. Öğretmen adaylarının meslek hayatlarında etkili bir sınıf yönetimi sergilemek adına sınıf yönetimi ve sınıf yönetimine bağlı temel unsurları nasıl algıladıkları büyük bir öneme sahiptir. Bu doğrultuda gerçekleştirilmiş olan çalışmada fen bilgisi öğretmen adaylarının sınıf yönetimine yönelik bilişsel algıları değerlendirilmektir.

Çalışmaya katılan 64 öğretmen adayının sınıf yönetimi için 49 farklı metafor ürettikleri görülmüştür. Üretilen farklı metafor sayısının yüksek olması öğretmen adaylarının zihninde 
sınıf yönetimi kavramının çeşitli şekillerde çağrışım yaptığını destekler niteliktedir. Fen bilgisi öğretmen adaylarının sınıf yönetimini ifade ederken daha çok aile kavramının sahip olduğu özelliklere dayalı metaforlar oluşturdukları görülmüştür. “Aile” metaforunu “'birliktelik/bütünlük/paylaşım”, “'kontrol etme” ve “gereksinimleri karşılama” olmak üzere üç ana başlığın altında toplamaktadırlar. Birliktelik, bütünlük ve paylaşıma dayalı aile metaforlarında öğretmen adaylarının sınıf yönetiminde öğrencilerde aidiyet, bir bütünün parçası ya da bir grubun üyesi olma hissi oluşturulması gerektiği üzerinde durdukları anlaşılmaktadır. Bununla birlikte, sınıf yönetimine yönelik oluşturulan aile metaforlarında ailenin çocuk üzerindeki kontrolü ile öğretmenin öğrenci üzerindeki kontrolü birbirine benzetilmiştir. Aküzüm ve Nazlı (2017) benzer şekilde öğretmenlerin sınıf yönetimindeki başarılarını disiplin sağlama becerileri ile ilişkilendirmektedir. Diğer taraftan öğretmen adaylarının aile metaforunu kullanırken ebeveynlerin çocuğun ihtiyaçlarını gidermesi ile öğretmenin öğrencilerin gereksinimlerini karşılaması arasında benzer bir bağ kurdukları görülmektedir.

Öğretmen adaylarının sınıf yönetimi ile ilgili ürettikleri metaforları ortak özellikleri bakımından bir araya getirerek oluşturulan metaforik kategoriler arasında en çok metaforu içerisinde bulunduran kategori "kontrol etmek" olmuştur. Ekici ve Akdeniz'in (2018) çalışmalarında da aynı şekilde sınıf yönetimi ile ilgili sınıfta disiplini sağlama hususunda katılımcıların ürettikleri metaforlar en çok "kontrol altında tutmak" kategorisi altında yer almaktadır. Kontrol etmek öğrencileri yönetmek ve öğrenciler üzerinde otorite kurmak şeklinde açıklanmaktadır. Günümüzde sınıfı ve öğrencileri kontrol etmek kurallarla, ödül ve cezalar ile öğrenciler üzerlerinde otorite kurmanın ötesine geçmiştir. İyi bir sınıf yönetimi ve öğrencileri istendik sınıf içi davranışlara yönlendirmenin yolu dersi onlar için ilginç ve merak uyandıracak bir hâle getirerek farklı teknik, yöntem, araç-gereç vb. ile çeşitlendirmekten geçmektedir. Bu noktada güdüleme, zaman yönetimi, etkili iletişim ve değerlendirme gibi unsurlar da işin içine girmektedir. Aslında sınıf yönetiminde disiplin ve otoriteyi sağlamak dersi en verimli şekilde planlama ve işleme yollarını bulmaktan geçmektedir.

En çok metaforun birleştiği ikinci metaforik kategori başlı̆ğ ise “birliktelik/bütünlük/paylaşım”, olarak saptanmıştır. Bu kategori başlığı altında öğretmen adaylarının sınıf yönetiminde öğretmen ile öğrenci arasındaki etkileşimin ve kurulan iletişim kanalının ne kadar önemli olduğu vurgulanmaktadır. Öğretmen ve öğrencinin birbirini tamamlayan unsurlar olduğu üzerinde durulmaktadır. Gülbahar ve Sıvacı (2018) benzer şekilde 
çalışmalarında sınıf yönetimi becerilerinin geliştirilmesinde öğretmen adaylarının iletişim becerilerinin önemli rol oynadığına değinmektedirler.

Diğer taraftan öğretmen adaylarının sınıf yönetimine ilişkin bilişsel algılarını kavramsal açıdan değerlendirmek için KİT uygulanarak “sınıf yönetimi”, “öğretmen”, “yönetici” ve “lider” anahtar kavramlarına yönelik türetmiş oldukları kelimeler incelenmiştir. KİT aracılığı ile anahtar kavramların her biri için türetilmiş olan kelimelerin sayısı ve niteliği o kavramın bilişsel açıdan ne derece kavranıp kavranmadığına yönelik bize fikir vermektedir. $\mathrm{Bu}$ nedenle bir kavramın anlaşılma derecesi o kavramın ifade edildiği kelimelere bağlıdır (Bahar ve diğ., 2006). Az sayıda kelime ile ilişsilendirilen bir kavram için yeteri kadar zihinde anlamlandırılamadığı yorumu yapılabilir (Ercan, Taşdere ve Ercan, 2010). Bu noktadan yola çıkarak elde edilen verileri değerlendirecek olursak "sınıf yönetimi'” (570 kelime) ve “lider”' (564) anahtar kavramlarının, “öğretmen”' (693 kelime) ve “yönetici” (609 kelime) anahtar kavramlarına göre öğretmen adaylarının zihninde daha az anlamlandırıldı̆̆ sonucuna varabiliriz.

Fen bilgisi öğretmen adaylarının çoğunun sınıf yönetimi kavramını “öğretmen”’ ve ‘’öğrenci”’ kelimeleri ile ilişkilendirdikleri tespit edilmiştir. Öğretmenin sınıf yönetiminde en önemli role sahip olan unsur olduğunda hemfikirler. Bu nedenle sınıf yönetimini öğretmenin karakteristik yapısının bir yansıması olarak değerlendirmektedirler. Özden (2007) çalışmasında benzer şekilde öğretmenin kişiliğine yönelik özelliklerin sınıf içerisinde oluşan ortamda görüldüğünü savunmuştur. Bu kavramların ardından ise “sınıf ortamı” kelimesi gelmektedir. Sınıf yönetimini etkilen değişkenlerin öğretmen, öğrenci, iletişim ve fiziksel ortam olduğunu düşünecek olursak bu değişkenlere paralel kelimelerin sıklıkla türetilmesi beklendik bir sonuç olarak düşünülebilir. Ancak iletişime yönelik kelimelerin öğretmen adayları tarafından tercih edilmemesi sınıf yönetiminde bahsetmiş oldukları öğretmen ve öğrenci unsurları arasında kurulması gereken iletişim kanalını ve etkileşimin rolünü gözden kaçırdıklarına işaret etmektedir.

Elde edilen verilere göre öğretmen anahtar kavramının ise ağırlıklı olarak diğer bir anahtar kavram olan “lider”' kelimesi ile ifade edildiği görülmektedir. Ancak öğretmen adaylarının “öğretmen”' kavramı ile “lider”’ kavramı arasında bağlantı kurmalarına rağmen “'sınıf ortamı”’ ve “okul’” kelimeleri ile “'lider”' kavramını hiç ilişkilendirmedikleri dikkat çekmektedir. Bu durum eğitim yöneticisi ve eğitim (sınıf) lideri kavramlarına yönelik öğretmen adaylarının yeterli hazırbulunuşluk ve farkındalığa sahip olmadıklarını ve bu konuda geliştirilmeye ihtiyaç duydukları şeklinde yorumlanabilir. 
Öğretmen adaylarının öğretmen anahtar kavramı için “'lider”’ kelimesinden sonra en çok türetmiş oldukları diğer kelime ise “bilgi’’dir. Öğretmen açısından bilgi donanımı branşına yönelik alan hâkimiyetiyle eşdeğerdir. Kültürel birikimi de bu bilgi zenginliğini geliştirmektedir. Sınıf yönetiminde öğretmenin alan bilgisi “bilgi otoritesi”' şeklinde yorumlanabilmektedir. Bilgi otoritesi ile bir öğretmen öğrenciye vermek istediği bilgiyi derinlemesine ve öğrencilere uygun olan her biçime sokarak sunma becerisini gösterir. Böylelikle öğrencide merak uyandırarak derse etkin katılımlarını sağlayabilir. Bunun doğal sonucu olarak başarılı bir sınıf yönetimi sergilemiş olur.

Öğretmen adaylarının “yönetici”, anahtar kavramını açıklarken “müdür” kelimesini ön plana çıkardıklarını bununla birlikte “öğretmen”, “disiplin”, ve “lider”, gibi farklı kelimeler etrafinda toplandıkları dikkat çekmektedir. Okul yöneticisi olarak müdürün; öğretmenleri güdüleme ve kendilerini işlerine adamalarını, eğitim-öğretimin amaçları doğrultusunda gerçekleşmesini ve geliştirilmesini sağlamada belli yeterliliklere sahip olması istenmektedir (Akçay, 2003). Bu nedenle müdürlerin belli yönetim becerilerine sahip olmaları ve bu beceriler doğrultusunda okulu yönetmeleri beklenmektedir. Akan, Yalçın ve Yıldırım (2014) benzer şekilde çalışmalarında öğretmenlerin müdür kavramına yönelik geliştirdikleri metaforlarda ağırlıklı olarak “yönetim”, kavramı üzerinde durduklarını vurgulamaktadırlar. Ayrıca öğretmenlerin üretmiş oldukları metaforlar doğrultusunda böyle bir algının oluşmasına okul yöneticilerinin gücü elinde bulunduran ve son kararı veren, aynı zamanda kararlarına itaat edilmesini isteyen bir yapıda olması sebep gösterilmektedir. Örücü (2014) çalışmasında bu sonucu destekler nitelikte okul yöneticisinin en çok otokrasi kavramsal teması içerisinde yer alan metaforlar ile ifade edildiğini belirtmektedir.

Fen bilgisi öğretmen adaylarının lider anahtar kavramını ise birçok farklı kelime ile ilişkilendirdikleri ancak az da olsa “Atatürk” ve “öğretmen”' kelimelerini diğerlerine göre daha ön plana çıkardıkları görülmektedir. Atatürk kelimesinin Atatürk’ün karakteristik özellikleri olan öngörülü olma, sorumluluk alma, önderlik etme (aynı zamanda lider anahtar kavramına yönelik üçüncü, dördüncü ve beşinci en çok türetilen kelimeler) kavramlarını bir arada bulundurmasından dolayı daha çok tercih edildiği düşünülebilir.

Öngörü, lider karakterli öğretmenden beklenmektedir. Fen bilgisi öğretmeleri ve öğretmen adayları başarılı bir sınıf yönetimi gerçekleştirmek için nasıl öngörülü davranabilir? Örneğin, 2023 eğitim vizyonu ile beceri-tasarım atölyeleri önem kazanmaktadır. Bu atölyelere yönelik düzenlemeler, etkinlik planlama çalışmaları yapılabilir. Dijital içerik geliştirme ve bilgisayar destekli fen dersleri düzenleme bulunduğumuz uzaktan eğitim süreci içerisinde 
dersin kalitesini ve öğrencinin katılımını artıracaktır. Bunun doğal sonucu olarak etkili bir sınıf yönetimi gerçekleştirilmiş olacaktır. Derste işlenen konularla ilgilenen ve konuya dair belli etkinliklerle meşgul olan öğrenci sınıf düzenini bozmayacak, istenmeyen davranışlarda bulunmayacaktır.

Kesme noktalarına göre anahtar kavramlara yönelik türetilen kelimelerden oluşturulan kavram ağında “lider” dışında diğer tüm anahtar kavramların “okul” kelimesi üzerinde durduğu görülmektedir. Bu durum okul ikliminin sınıf yönetiminde başarıya giden yolda önemli bir role sahip olduğunu göstermektedir. Aynı zamanda öğretmen adaylarının lider anahtar kavramını okul kelimesi ile ilişkilendirmemiş olması eğitim lideri (yöneticisi) olgusunu zihinlerinde oturtmada eksiklikler yaşadıklarına işaret etmektedir.

Metaforik kategorilerden en çok tercih edileni kontrol etmek (yönetmek, otorite) olurken bu duruma paralel olarak KİT aracılığıyla kurulan cümlelerin de benzer şekilde disiplin (hâkimiyet, kontrol etme) üzerinde yoğunlaştığı görülmektedir. Ekici ve Akdeniz (2018) sınıf yönetimini “disiplin sağlamak” kavramı üzerinden değerlendirdikleri çalışmalarında öğretmenlerin sınıfı kontrol altında tutmak ve öğrenciler üzerinde baskı kurmak yönünde algıladıklarını belirtmektedirler.

Metaforik kategoriler arasında en çok tercih edilen ikinci başlık olan “'birliktelik/bütünlük/paylaşım”, ile KİT aracılığıyla kurulan cümleler içerisinde “iletişim”, kavramının ön plana çıkması yine her iki veri toplama kaynağından elde edilen verilerin aynı sonucu işaret ettiğini göstermektedir. Çünkü sınıf ortamında öğretmen ve öğrencinin birlik ve beraberlik oluşturması ve bir bütünün parçaları gibi hareket edebilmeleri iyi bir iletişim kanalı oluşturmaları ve sürekli etkileşimde bulunmaları ile mümkündür.

Çalışmaya katılmış olan fen bilgisi öğretmen adaylarının sınıf yönetimi dersini almış olmalarına karşın olumlu sınıf iklimi (ortamı), sınıf kuralları, zaman yönetimi ve lider öğretmen gibi kavramları yeterli derecede türetmedikleri tespit edilmiştir. Sınıf yönetimi içerisinde büyük öneme sahip olan bu kavramları hâlen kafalarında net olarak oturtamadıkları anlaşılmaktadır. $\mathrm{Bu}$ durum, çalışmanın önemini belirtirken öğretmen adaylarının sınıf yönetimine bakış açılarının daha etkili bir rehberlikle istendik yönde geliştirilmesine yönelik gereksinimlerin bulunduğunun bir göstergesidir.

\section{Öneriler}

$\mathrm{Bu}$ çalışma sınıf yönetiminde başarı yakalamanın öğrenciyle içten ve samimi yollarla etkileşim kurmaktan geçtiğini göstermektedir. Bunu sağlayabilmek için öğrencilerin ilgi, ihtiyaç ve becerilerinin net bir şekilde belirlenmesi ve bu doğrultuda derslerin işlenişinin 
şekillendirilmesi gerekmektedir. Gerek öğretmen adaylarının gerekse de öğretmenlerin pedagojik bilgilerini geliştirmeleri gerektiği kaçınılmaz bir gerçektir. Öğrencileri tanımak ve onlara uygun olan öğretim yaklaşımlarını belirlemek için öğretmenlerin harcayacakları süre bir zaman kaybı olarak görülmemeli aksine zaruri bir ihtiyaç gözüyle bakılarak değerlendirilmelidir.

Öğretmenlerin eğitim yöneticisi (eğitim lideri) misyonunun gerekliliklerini yerine getirebilmesi hususunda alan bilgisi (bilgi otoritesi) ve öğrenci profiline uygun yaklaşımları uygulama noktasında kendilerini üst düzeyde yetiştirmeleri gerekmektedir. $\mathrm{Bu}$ durum da pedagojik alan bilgisini iyi oturtmuş öğretmenlerin sınıf yönetiminde istedikleri başarıya ulaşabileceklerini göstermektedir. Özellikle öğretmen yetiştiren programlarda sınıf yönetimi becerisinin alan bilgisi ve pedagojik bilgi ile desteklenerek geliştirilmesi gerekliliğini ortaya koymaktadır.

Diğer branşlardan öğretmen ve öğretmen adaylarının da sınıf yönetimine yönelik metaforik ve bilişsel algılarını bir arada inceleyen çalışmalar yapılabilir ve sonuçlar karşılaştırılarak benzer ve farklı yönler ortaya konulabilir. Daha büyük örneklem grupları üzerinden de fen bilgisi öğretmenlerinin ve öğretmen adaylarının sınıf yönetimine ilişkin metaforik ve bilişsel algılarını inceleyen çalışmalar gerçekleştirilebilir.

Sınıf yönetiminde öğretmen, yönetici ve lider (yol gösteren) kavramlarının birbirleri ile ilişkisini göz önünde bulundurarak öğretmenin sadece rehber olmakla kalmayan aynı zamanda mentörlük de eden bir profile sahip olması ihtiyacı duyulmaktadır. Öğretmen adaylarının bu doğrultuda bir eğitim alması ve vizyon geliştirmesi için öğretmen yetiştiren programlarda meslek bilgisi bünyesinde derslerin içeriğinin yeniden düzenlenmesinde fayda vardır.

\section{Sinırlılıklar}

Araştırmanın örneklem sayısından ve örneklemin belli bir üniversite dikkate alınarak oluşturulmasından kaynaklanan etki değerine bağlı sınırlılıklardan bahsedebiliriz. Bu nedenle elde edilen veriler üzerinden yapılan yorumlarda genellemelerde bulunulmamaktadır. Tavsiye niteliğinde değerlendirmeler yapılmaktadır.

\section{Makalenin Bilimdeki Konumu}

Matematik ve Fen Bilimleri Eğitimi/Fen Bilgisi Eğitimi

Eğitim Bilimleri/ Eğitim Yönetimi

\section{Makalenin Bilimdeki Özgünlüğü}

Alan yazında fen bilgisi öğretmen adaylarının sınıf yönetimi algıları üzerine gerçekleştirilen çalışmaların sınırlı olduğu görülmektedir. Bununla birlikte mevcut 
çalışmaların genel olarak tercih edilen öğretim yöntemleri ya da iletişim becerileri üzerinden öğretmen adaylarının sınıf yönetimi algılarını değerlendirilmeye çalıştı̆̆ı tespit edilmiştir. Gerçekleştirilen bu çalışmada sınıf yönetiminin bütün boyutlarını (sınıf iklimi, zaman yönetimi, öğretim yöntemleri, araç-gereç kullanımı, disiplin, plan-program, iletişim vb.) dikkate alarak öğretmen adaylarının bilişsel algıları ifade edilmiştir. Yine diğer çalışmalardan farklı olarak öğretmen adaylarının bilişsel algıları tek bir açıdan değil farklı boyutları bir arada ele alarak hem kavramsal ilişkilendirme hem de metaforik algı kapsamında incelenmeye alınmıştır. Araştırmanın elde edilen veriler ile özellikle öğretmen yetiştiren programlarda eğitmenlerin sınıf yönetimi başta olmak üzere mesleki bilgiye dayalı derslerini daha etkili bir şekilde planlamalarına katkı sağlayacağı düşünülmektedir.

\section{Kaynaklar}

Ağaoğlu, E. (2001). Sınıf yönetimiyle ilgili genel olgular. Z. Kaya (Ed.), Sinıf yönetimi. Ankara: Pegem Akademi Yayıncılık.

Akan, D., Yalçın, S., \& Yıldırım, İ. (2014). “Okul Müdürü” kavramına ilişkin öğretmenlerin metaforik algıları. Illkögretim Online, 13(1), 169-179.

Akçay, A. (2003). Okul müdürleri öğretmenleri etkileyebiliyor mu? Milli Ĕ̆itim Dergisi, 157, Kış 2003.

Aküzüm, C. \& Nazlı, K. (2017). Sınıf öğretmenlerinin sınıf yönetiminde karşılaştıkları disiplin sorunları, nedenleri ve bu sorunlarla baş etme yöntemlerinin değerlendirilmesi. International e-Journal of Educational Studies (IEJES), 1(2), 88-102.

Aydın, A. (1998). Sinıf yönetimi. Ankara: Anı Yayıncılık.

Bahar, M., Johnstone, A. H., \& Sutcliffe, R. G. (1999). Investigation of students' cognitive structure in elementary genetics through word association tests. Journal of Biological Education, 33, 134-141.

Bahar, M., \& Özatlı, S. (2003). Kelime ilişkilendirme testi yöntemi ile lise 1. sınıf öğrencilerinin canlıların temel bileşenleri konusundaki bilişsel yapılarının araştırılması. Balıkesir Üniversitesi Fen Bilimleri Enstitüsü Dergisi, 5, 75-85.

Bahar, M., Nartgün, Z., Durmuş, S. \& Bıçak, B. (2006). Geleneksel ve alternatif ölçme ve değerlendirme öğretmen el kitabı. Ankara: Pegem Akademi.

Başar, H. (2001). Sinıf yönetimi. Ankara: Pegem Akademi.

Blackstone, A. (2012). Sociologocal inquiry principles: Qualitative and quantitative methods. Irvington, NY: Flat World Knowledge. 
Bogdan, R.C., \& Biklen, S.K. (2007). Qualitative research for education (5 ${ }^{\text {th }}$ ed). Boston: Pearson Education, Inc.

Brophy, J. (2006). History of research on classroom management. In C. M. Evertson, \& C. S. Weinstein (Eds.), Handbook of classroom management. Research, practice, and contemporary issues (pp. 17-43). Mahwah N.J.: Lawrence Erlbaum.

Büyüköztürk, Ş., Çakmak, E. K., Akgün, Ö. E., Karadeniz, Ş., \& Demirel, F. (2016). Bilimsel araştırma yöntemleri. Ankara: Pegem Akademi.

Cohen, L., Manion, L., \& Morrison, K. (2007). Research methods in education. New York, NY: Routledge.

Creswell, J. W. (2012). Educational research: Planning, conducting and evaluating quantitative and qualitative research $\left(4^{\text {th }}\right.$ ed.). Boston: Pearson.

Creswell, J. W. (2013). Qualitative inquiry and research design: Choosing among five approaches. Thousand Oaks, CA: Sage.

Creswell, J. W., \& Creswell, J. D. (2018). Research design: qualitative, quantitative, and mixed methods approaches (5th ed.). Thousand Oaks, California; London; New Delhi: Sage Publications.

Crow, N. (1991). Personal perspectives on classroom management. Paper presented at the Annual Meeting of the American Educational Research Association, Chicago, IL (Eric Document Reproduction Service No. ED 332 959) Retrieved from http://www.eric.ed.gov/

Çocuk, H. E., Yokuş, G., \& Tanrıseven, I. (2015). Pedagojik formasyon öğrencilerinin öğretmenliğe ilişkin öz-yeterlik ve metaforik algıları: Mersin Üniversitesi örneği. Mustafa Kemal Üniversitesi Sosyal Bilimler Enstitüsü Dergisi, 12(32), 373-387.

Demirel, Ö. (2000). Plandan uygulamaya öğretme sanatı. Ankara: Pegem Akademi.

Demirtaş, H. (2007). Sınıf yönetiminin temelleri. H. Kıran (Ed.), Etkili sınıf yönetimi (s. 241275). Ankara: Anı Yayıncılık.

Doyle, W. (1986). Classroom organization and management. In M. C. Wittrock, (Ed.), Handbook of research on teaching. ( $3^{\text {rd }}$ ed.). (pp. 392-431). New York: Macmillan.

Ekici, G., \& Akdeniz, H. (2018). Öğretmen adaylarının "sınıfta disiplin sağlamak" kavramına ilişkin algılarının belirlenmesi: Bir metafor analizi çalışması. Dicle Üniversitesi Ziya Gökalp Ĕgitim Fakültesi Dergisi, 33, 26-37.

Englander, M. E. (1986). Strategies for classroom disipline. New York: Praeger. 
Ercan, F., Taşdere, A., \& Ercan, N. (2010). Kelime ilişkilendirme testi aracılığıyla bilişsel yapının ve kavramsal değişimin gözlenmesi. Türk Fen Eğitimi Dergisi, 7(2), 136-154.

Gülbahar, B., \& Sıvacı, S. Y. (2018). Öğretmen adaylarının iletişim becerileri ile sınıf yönetimi yeterlik algıları arasındaki ilişkinin incelenmesi. YYÜ Ĕ̆itim Fakültesi Dergisi, 15(1), 268-301.

McCormack, A. (1997). Classroom management problems, strategies, and influences in physical education. European Physical Education Review, 3(2), 102-115.

Merriam, S. B. (1998). Qualitative research and case study applications in education. San Francisco: Jossey-Bass.

Miles, M. B., \& Huberman, A. M. (1994). Qualitative data analysis ( $2^{\text {nd }}$ ed.). Thousand Oaks, CA: SAGE.

Ming-Tak, H., \& Wai-Shing, L. (2008). Classroom management: creating a positive learning environment. Hong Kong University Press.

Murdick, N. L., \& Hogan, B. P. (1996). Inclusive classroom management: Using preintervention strategies. Intervention in School and Clinic, 31(3), 172-176.

Önal, N. (2017). Bilişim teknolojileri öğretmen adaylarının bölümlerine yönelik bilişsel algılarının kit aracılığıyla incelenmesi. Ahi Evran Üniversitesi Kırşehir Ĕ̈itim Fakültesi, 18(2), 255-272.

Örücü, D. (2012). İlköğretim sınıf öğretmenlerinin sınıfa ve sınıf yönetimine ilişkin metaforik bakışları: Karşılaştırmalı bir durum çalışması. Illköğretim Online, 11(2), 342-352.

Örücü, D. (2014). Öğretmen adaylarının okul, okul yönetimi ve türk eğitim sistemine yönelik metaforik algıları. Kuram ve Uygulamada Eğitim Yönetimi, 20(3), 327-358.

Özatlı, N. S., \& Bahar, M. (2010). Öğrencilerin boşaltım sistemi konusundaki bilişsel yapılarının yeni teknikler ile ortaya konması. Abant İzzet Baysal Üniversitesi Ĕ̈itim Fakültesi Dergisi. 10(2), 9-26.

Özdemir, S. M. (2017). Sınıf yönetimine ilişkin temel kavramlar. G. Yüksel ve S. Filiz Büyükalan (Eds.), Sinıf yönetimi (s. 1-22). Ankara: Pegem Akademi.

Özden, Y. (2007). Sınıf içinde öğrenme öğretme ortamının düzenlenmesi. E. Karip (Ed.), Sınıf yönetimi (s. 36-68). Ankara: Pegem Akademi.

Rivera, F. D., \& Becker, J. R. (2008). Middle school children's cognitive perceptions of constructive and deconstructive generalizations involving linear figural patterns. ZDM Mathematics Education 40, 65-82. 
Saban, A. (2009). Öğretmen adaylarının öğrenci kavramına ilişkin sahip oldukları zihinsel imgeler. Türk Eğitim Bilimleri Dergisi, 7(2), 281-326.

Shavelson, R. J. (1974). Methods for examining representations of A subject-matter structure in a student's memory. Journal of Research in Science Teaching 11(3), 231-249.

Stronge, J.H., Tucker, P.D., \& Hindman, J.L. (2004). Handbook for qualities of effective teachers. Association for Supervision and Curriculum Development, Alexandria, VA, USA.

Weber, A. W. (2004). Classroom management. In J. M. Cooper (Ed.), Classroom teaching skills. Massachusettes: D.C. Heath and Company.

Zeiger, A. (2000). The keys to classroom management. Teaching Music, 7(6), 24-30.

\section{Summary}

\section{Statement of Problem}

The classroom environment has an important role in shaping the behaviors, attitudes and values of students in their educational life and in the professional development of teachers (Özdemir, 2017). Thus, it is the most important place where teachers exhibit their pedagogical content knowledge. Classroom management skills are also needed to bring together the teaching style of the teacher and the learning style of the student on a common ground.

Many studies emphasize that pre-service teachers and novice teachers struggle with difficulties and concerns about classroom management Crow, 1991; McCormack, 1997). However, few studies dwell on how pre-service teachers perceive classroom management (Örücü, 2012; Ekici \& Akdeniz, 2018). The concept of classroom management is difficult to perceive as it depends on many factors. Therefore, knowing the perceptions of pre-service teachers about classroom management by educators will help them to apply more effective methods in developing their classroom management skills. Classroom management has a structure that includes different dimensions and gathers around six main topics. These are; physical environment of the classroom, teacher lesson preparation and lecturing methods, student behavior regulation (discipline), organizing in class relations (communication), plan and program activities, and time management (Başar, 2001; Demirtaş, 2007)

\section{Purpose of the Study}

The aim of the study was to determine the cognitive perceptions of pre-service science teachers relevant to school management. The study was addressed by the following research questions: 
1) Which metaphors do pre-service science teachers describe their cognitive perceptions towards the concept of classroom management?

2) Under which conceptual categories the metaphors that pre-service science teachers produce for classroom management?

3) What are the words that pre-service science teachers derived for key concepts related to classroom management with respect to the WAT?

4) How do pre-service science teachers explain their cognitive perceptions concerning classroom management with respect to the WAT?

\section{Method}

In this study, cross-sectional scanning which is one of the types of scanning method was used. This research design was employed since cross-sectional scanning has been used to measure current attitudes and situations (Creswell, 2012). 64 pre-service science teachers (48 females and 16 males) enrolled in Kastamonu University during 2019-2020 academic semester constitute the sample of the study. All of the pre-service science teachers in the study group have taken the classroom management course in the previous semester. "Classroom Management Perception Form', was applied to identify cognitive perceptions of the participants aspect of their metaphorical and conceptional perspectives. Cognitive perceptions of pre-service science teachers towards the concept of classroom management were interpreted through produced metaphors, derived concepts, descriptive sentences and created categories. The data obtained in the study were analyzed by referring to content analysis.

\section{Findings}

The first research question is addressed metaphors of pre-service science teachers towards the concept of classroom management. This analysis is presented in Table 1 . The findings indicate that the metaphor of family is the most preferred metaphor among the produced metaphors. The metaphors of brain, father, universe, sun and country government are also included as metaphors produced by pre-service teachers several times. Family metaphor has been used in different meanings while explaining the concept of classroom management. These are described under the category titles of "unity/integrity/sharing”, “controlling”, “meeting the requirements" and "considering physical/personal characteristics"'.

The second research question defined metaphorical categories towards the concept of classroom management according to the produced metaphors. Obtained metaphorical 
categories are presented in Table 2. The categories containing the most metaphors are "Controlling”, and "Unity/Integrity/Sharing”.

Third research question determined the most derived words for each key concept related to classroom management through WAT. This analysis is presented in Table 3, 4, 5, 6 and 7. Based on the findings, pre-service science teachers mostly derived words (693 words) for the teacher key concept. This is respectively followed by the number of words derived for the key concept “'manager”' (609 words), “classroom management”' (570 words) and “'leader”' (564 words). For the key concept of classroom management, pre-service science teachers derived the words teacher and student more than other words. Almost half of the participants derived leader word for the key concept of teacher. Wise draws attention as the second most derived word regarding teacher key concept. The key concept of administrator was often related with the word manager. Last, Atatürk and teacher mostly derived words for the key concept of leader. The concept network remarks that the word school is among the most commonly derived words for all key concepts except for the leader key concept.

The descriptive sentences presented for classroom management addresses fourth research question. Based on the findings the preservice teachers especially emphasized "the concepts of discipline”, “communication”, “plan-program”, and “time management”.

\section{Discussion and Conclusion}

In the family metaphors - which is the most produced metaphor - for classroom management, the control of the family over the child and the control of the teacher over the student are resembled to each other. Aküzüm and Nazlı (2017) supportively related success of teachers in classroom management with their ability to provide discipline. In addition, preservice teachers relate the parents' meeting the needs of the child and the teacher meeting the needs of the students while using family metaphor.

Pre-service teachers also produced the greatest number of the metaphors under “'Controlling”' metaphorical category. They explain this metaphorical category as managing students and establishing authority over them. An effective classroom management is possible by making the course interesting for the students. For this, teachers should benefit from various techniques, methods, and materials. They should also consider the factors such as motivation, time management, effective communication and evaluation.

According to the concept network, almost all the key concepts emphasize that the word of "school”. This means school related issues as school climate has an important role in successful classroom management. On the other hand, the concept network indicate that the 
pre-service teachers inappropriately connect the concept of “leader”' key with the word school. Therefore, they have deficiencies in the concept of teacher being educational leader in education.

Both the metaphorical category of "unity/integrity/sharing”' and written sentences through WAT highlight the concept of communication. This situation is a result of the necessity of creating a good communication channel for the teacher and student in the classroom environment to act in unity and as a part of a whole.

Keywords: Cognitive perception, pre-service science teachers, metaphor, the Word Association Test (WAT), classroom management.

\section{Etik Kurul Kararı}

Kastamonu Üniversitesi Sosyal ve Beşerî Bilimler Araştırma ve Yayın Etik Kurulu'nun, 30/06/2020 tarih ve 2 sayılı kararı gereği çalışma açısından Sosyal ve Beşerî Etik Kuralları ve İlkeleri çerçevesinde herhangi bir sakınca olmadığına karar verilmiştir. 